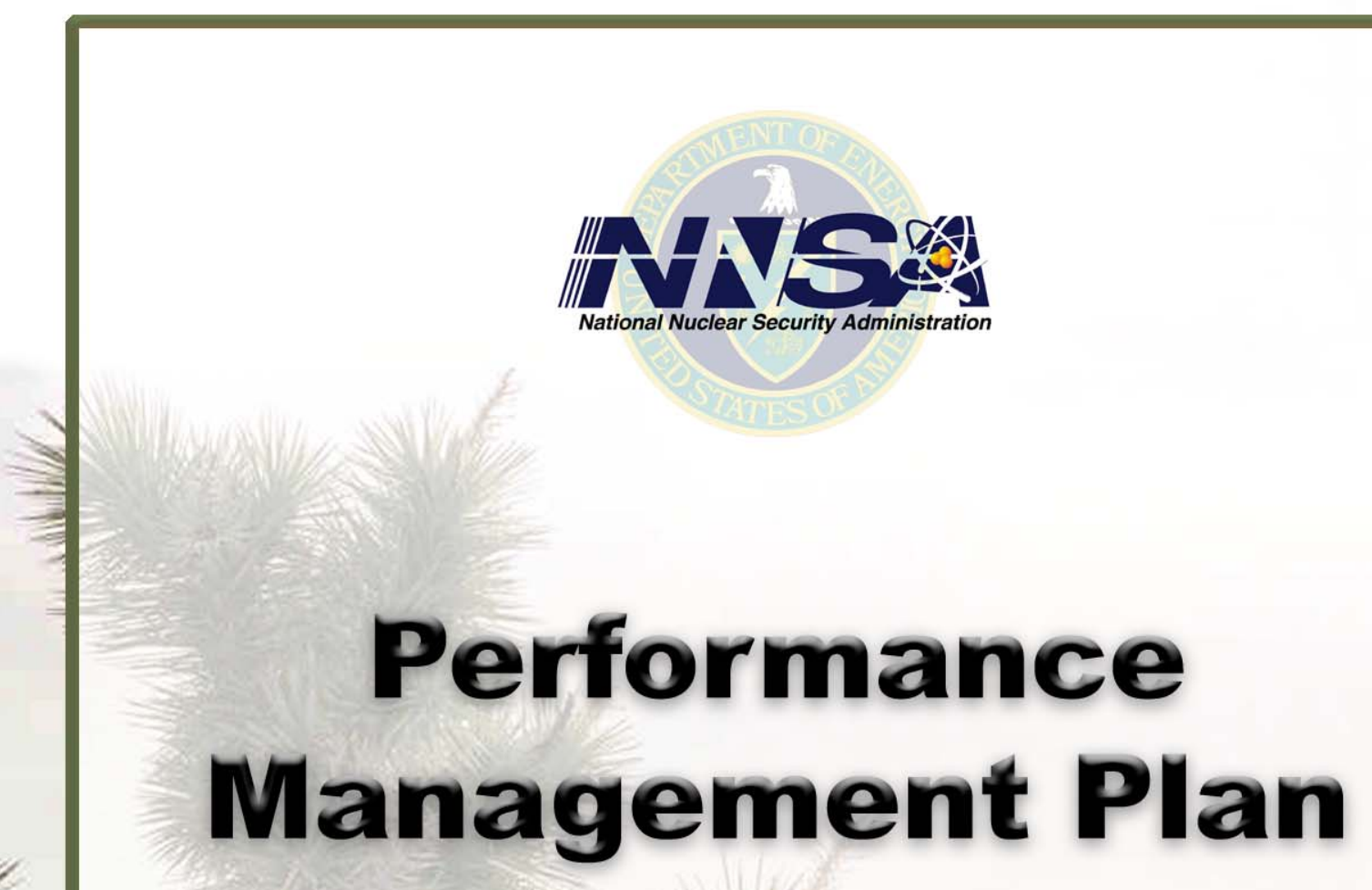

U.S. Department of Energy National Nuclear Security Administration Nevada Operations Office

\title{
August 2002
}




\section{U.S. Department of Energy National Nuclear Security Administration Nevada Operations Office}

\section{Environmental Management}

\section{Performance Management Plan}

August 2002 


\section{Table of Contents}

$1.0 \quad$ Executive Summary $\ldots \ldots \ldots \ldots \ldots \ldots \ldots \ldots \ldots \ldots \ldots \ldots \ldots \ldots$

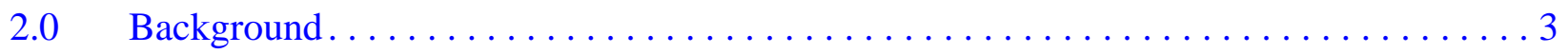

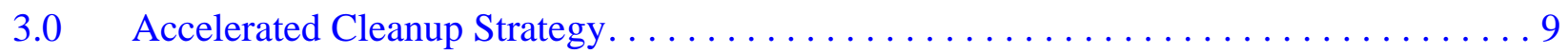

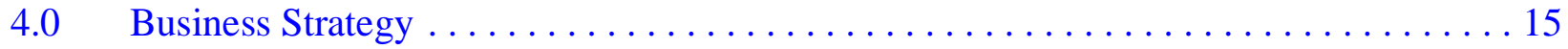

4.1 Management Roles and Responsibilities . . . . . . . . . . . . . . 15

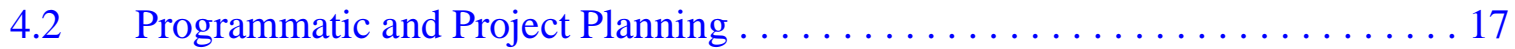

4.3 Managing Risk and Uncertainty . . . . . . . . . . . . . . . 18

4.4 Managing Contracts . . . . . . . . . . . . . . . . . . . . . 19

4.5 Regulator and Stakeholder Interactions . . . . . . . . . . . . . . . 19

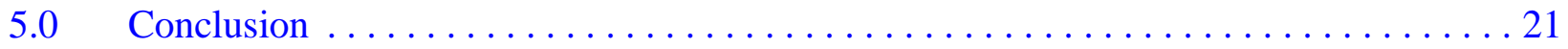

Appendix A - Master Schedule

Appendix B - Challenges

Appendix C - Government Furnished Services

Appendix D - Letter of Intent

Appendix E - Commitment Letters

Appendix F - Endorsement Letters 


\subsection{EXECUTIVE SUMMARY}

This Performance Management Plan describes the approach for accelerating cleanup activities of U.S. Department of Energy (DOE), National Nuclear Security Administration Nevada Operations Office (NNSA/NV) Environmental Management (EM) Program. This approach accelerates the reduction of risk at NNSA/NV sites while performing the work responsibly, effectively, and more efficiently. In May 2002, NNSA/NV EM and the Nevada Division of Environmental Protection signed a Letter of Intent formalizing an agreement to pursue accelerated risk reduction and cleanup for activities within the State of Nevada. This Performance Management Plan provides the strategic direction for implementing the Letter of Intent.

Historic NNSA/NV activities associated with atmospheric and underground nuclear testing activities conducted on the Nevada Test Site (NTS); the Department of Defense's Tonopah Test Range, Nevada Test and Training Range (formerly known as the Nellis Air Force Range); and nine other sites in five states (Alaska, Colorado, Mississippi, Nevada, and New Mexico) have resulted in contamination of sites, support facilities, soils, and groundwater. Cleanup of this contamination is complex due to the large number of contaminated sites, the nature and extent of the contamination, the size and location of many of the sites, and the number of State regulators involved in cleanup decisions (i.e., regulators from five states). In addition, the NTS is designated as a regional disposal site for low-level waste (LLW) and mixed low-level waste (MLLW) generated as the result of cleanup activities across the DOE complex. NNSA/NV EM is committed to ensuring that risk reduction at all of its sites will be achieved cost-effectively and efficiently, while effectively protecting workers, the public, and the environment and proactively addressing State regulator and stakeholder concerns. Simultaneously, NNSA/NV EM is committed to providing indispensable, efficient, cost-effective, quality low-level and mixed-low-level radioactive waste disposal capability for the DOE complex to meet the needs of other sites as they pursue their risk reduction and acceleration goals and objectives.

By 2010, risk reduction activities agreed to by NNSA/NV EM and State regulators will have occurred at all NNSA/NV EM sites, and the following objectives will be achieved:

- Closure of all 1,047 Industrial Sites on the NTS and Tonopah Test Range

- Establishment of a 1,000 picocuries per gram ( $\mathrm{pCi} / \mathrm{g})$ soils corrective action level and investigation and acceleration of soils cleanup activities on the NTS, Tonopah Test Range, and Nevada Test and Training Range

- Closure of the surface area of all of the nine former nuclear testing sites in five states and closure of the subsurface at two of those sites

- $\quad$ Shipment of legacy drums of transuranic (TRU) waste currently in storage at the NTS to the Waste Isolation Pilot Plant (WIPP) for disposal -- evaluation and implementation of new technology for TRU waste with no path forward for disposition (oversize boxes, classified materials in storage, and spheres)

- $\quad$ Continued cost-effective capability to receive large quantities of LLW from generators throughout the DOE complex

- $\quad$ Receive State approval of Resource Conservation and Recovery Act (RCRA) Part B Permit to receive MLLW from off-site generators

Under Cleanup Reform Account (CRA) funding, significant acceleration is accomplished for Industrial Sites (9 years), Soils (16 years), and TRU (2 years).

Activities remaining beyond 2010 are associated with maintaining waste disposal capability for the DOE complex, data acquisition and modeling required for the Underground Test Area (UGTA) to establish contaminant boundaries and develop a long-term monitoring network, completion of similar groundwater modeling and monitoring activities for the subsurface at the six remaining off-site locations, oversight by State regulators of remaining activities, and long-term stewardship activities. 
Significant progress has occurred since inception of the NNSA/NV EM program including:

- Completion of corrective actions at 630 Industrial Sites

- Tentative agreement reached with the U.S. Air Force and the State regulator on a Soils corrective action level of $1,000 \mathrm{pCi} / \mathrm{g}$

- Renegotiation of the UGTA corrective action strategy with the State of Nevada to allow a better understanding of the activity parameters and requirements of the State regulator and stakeholders

- Completion of Project Chariot, Central Nevada Test Area, Project Shoal, Rulison, Salmon Site, and Amchitka Island surface cleanup

- Completion of preparations for receipt of off-site generated MLLW and submission of a RCRA Part B Permit to the State of Nevada to cover receipt of MLLW from off-site generators

- Maintenance of cost-effective LLW disposal capability for the DOE complex $(1,632,856$ cubic feet in 1,137 shipments so far in FY 2002 [as of July 21, 2002])

Accelerating cleanup of NNSA/NV EM activities will reduce the risk of contamination from historical nuclear testing activities to workers, the public, and the environment; address State regulator and stakeholder high-priority issues and concerns; and allow further consolidation of EM activities to reduce costs and schedules.

NNSA/NV EM has a strong, cooperative relationship with its State regulators who have been firm, fair, and reasonable in their requirements and requests. NNSA/NV EM is committed to continuing these proactive, cooperative relationships, not only with regulators but with other stakeholders. These relationships will ensure activities remain highly focused on opportunities for further acceleration, address the highest risk activities, and proceed cost-effectively and efficiently in accordance with applicable regulations and requirements, Integrated Safety Management, and sound project management principles and practices.

NNSA/NV EM's commitment to cleanup reform is embodied in six strategic initiatives: (1) accelerate the cleanup of contaminated Industrial Sites; (2) accelerate soils corrective actions by establishing and implementing a Soils corrective action level of 1,000 pCi/g; (3) manage future risk to the public from contaminated groundwater by establishing contaminant boundaries; (4) negotiate strategies for corrective actions in other states similar to successful strategies used in the State of Nevada; (5) accelerate the disposition of TRU waste in storage at the NTS; and (6) maintain cost-effective, efficient, and safe LLW and MLLW disposal capability to meet the needs of the DOE complex.

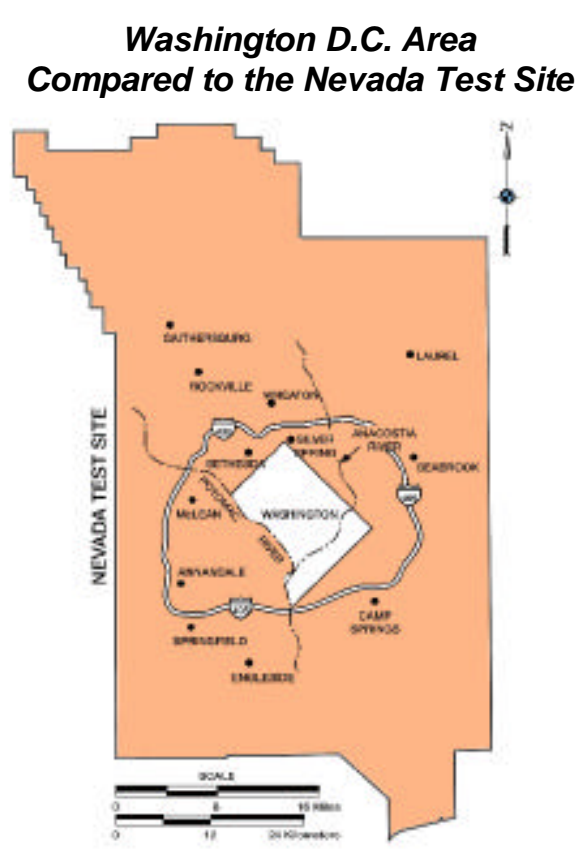

Management roles and responsibilities are shared by the Administrator, NNSA; the Assistant Secretary, Environmental Management, (EM-1); the DOE Headquarters EM Nevada Site Team; the Manager, NNSA/NV; the Assistant Manager,

Environmental Management, NNSA/NV; the General Manager, Management and Operating contractor; and the Program Manager, Architect/Engineer contractor. Working together with acceleration of NNSA/NV EM activities as a common goal, contract incentives will focus on achievement of the goals, objectives, strategies, and milestones/metrics identified in this Performance Management Plan.

The NNSA/NV EM Performance Management Plan is an ambitious undertaking -- the NTS alone is larger than any other DOE site in the complex, and activities cover the entire site as well as large components of the Department of Defense's Tonopah Test Range, Nevada Test and Training Range, and nine off-site locations in five states. In order to succeed, NNSA/NV EM must manage its limited resources wisely ensuring that its federal and contractor staff remain focused, efficient, and effective while maintaining proactive relationships with State regulators and stakeholders. 


\section{0 вАскGROUND}

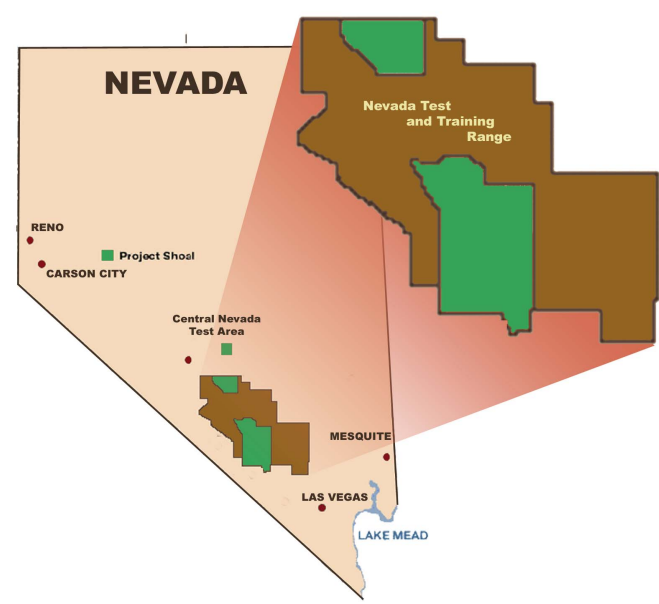

For over 40 years, the primary mission of the U.S. Department of Energy (DOE), Nevada Operations Office (now known as the National Nuclear Security Administration, Nevada Operations Office [NNSA/NV]) was to conduct tests of both nuclear and conventional explosives in connection with the research and development of nuclear weapons. Field testing was conducted primarily at the Nevada Test Site (NTS), although tests were also conducted at the Tonopah Test Range and the Nevada Test and Training Range (formerly known as the Nellis Air Force Range) which provide buffers surrounding the NTS.

Underground nuclear tests were also conducted at nine other sites in five states (Alaska, Colorado, Mississippi, Nevada, and New Mexico). In the 1950s, atmospheric tests were the predominant tests at the NTS; from August 1963 to October 1992 more than 900 nuclear tests were conducted, primarily underground. Underground nuclear testing ceased in October 1992, although a readiness posture is maintained at the NTS as required by Presidential directive. In addition, subcritical nuclear experiments are currently being conducted to obtain technical information in support of the DOE's responsibility to maintain the safety and reliability of the U.S. nuclear weapons stockpile without full-scale nuclear testing.

Environmental liabilities associated with these activities include environmental contamination, hazardous and radioactive wastes and materials, contaminated buildings and facilities, and long-term stewardship obligations.

The NNSA/NV Environmental Management (EM) Program supports the DOE complex by maintaining the essential capability to dispose of low-level waste (LLW), and beginning in fiscal year (FY) 2003, mixed low-level waste (MLLW) generated as the result of other sites' cleanup and risk reduction.

NNSA/NV EM has provided indispensable, cost-effective, efficient, and safe waste disposal capability since the inception of the DOE EM program and will remain open to serve the DOE complex until at least 2021 to ensure waste disposal capability exists to meet the requirements and needs of the national EM program. As of July 2002, a total

\section{Low-Level Waste Disposal Volumes at the NTS}

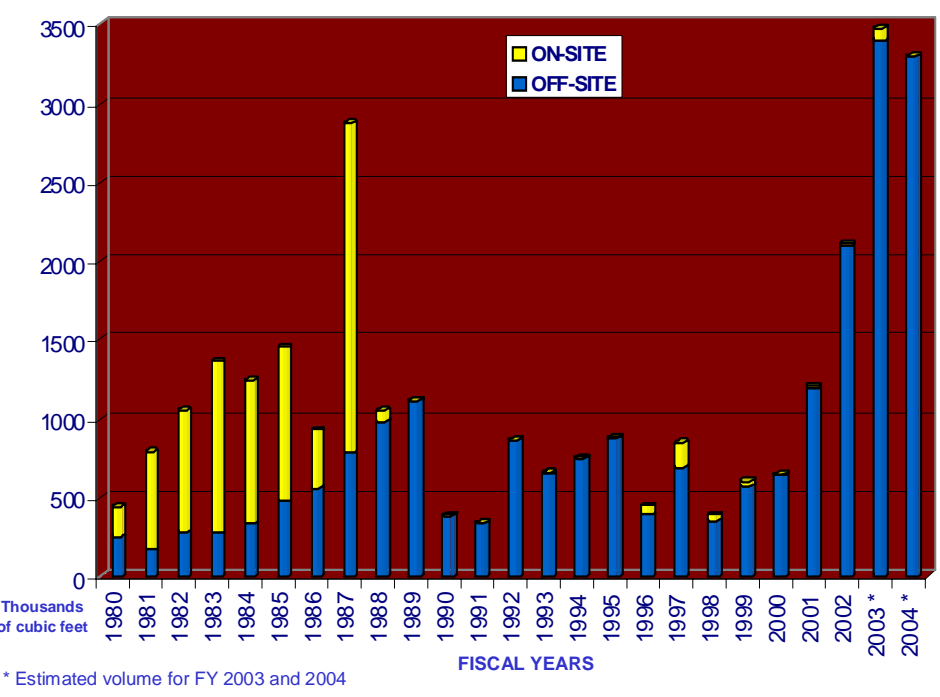


of 23,100,000 cubic feet of LLW and 300,000 cubic feet of MLLW has been disposed at the NTS. Disposal volumes are anticipated to increase dramatically in the next few years as a result of accelerated cleanup initiatives across the Complex. Approximately 99 percent of the waste forecast for disposal at the NTS in the next three years (as well as the last three years) originates from non-NNSA/NV off-site generators. The following figure indicates currently approved and potential generators that dispose radioactive waste at the NTS.

\section{Approved NTS Disposal Generators and Other Potential Sites}

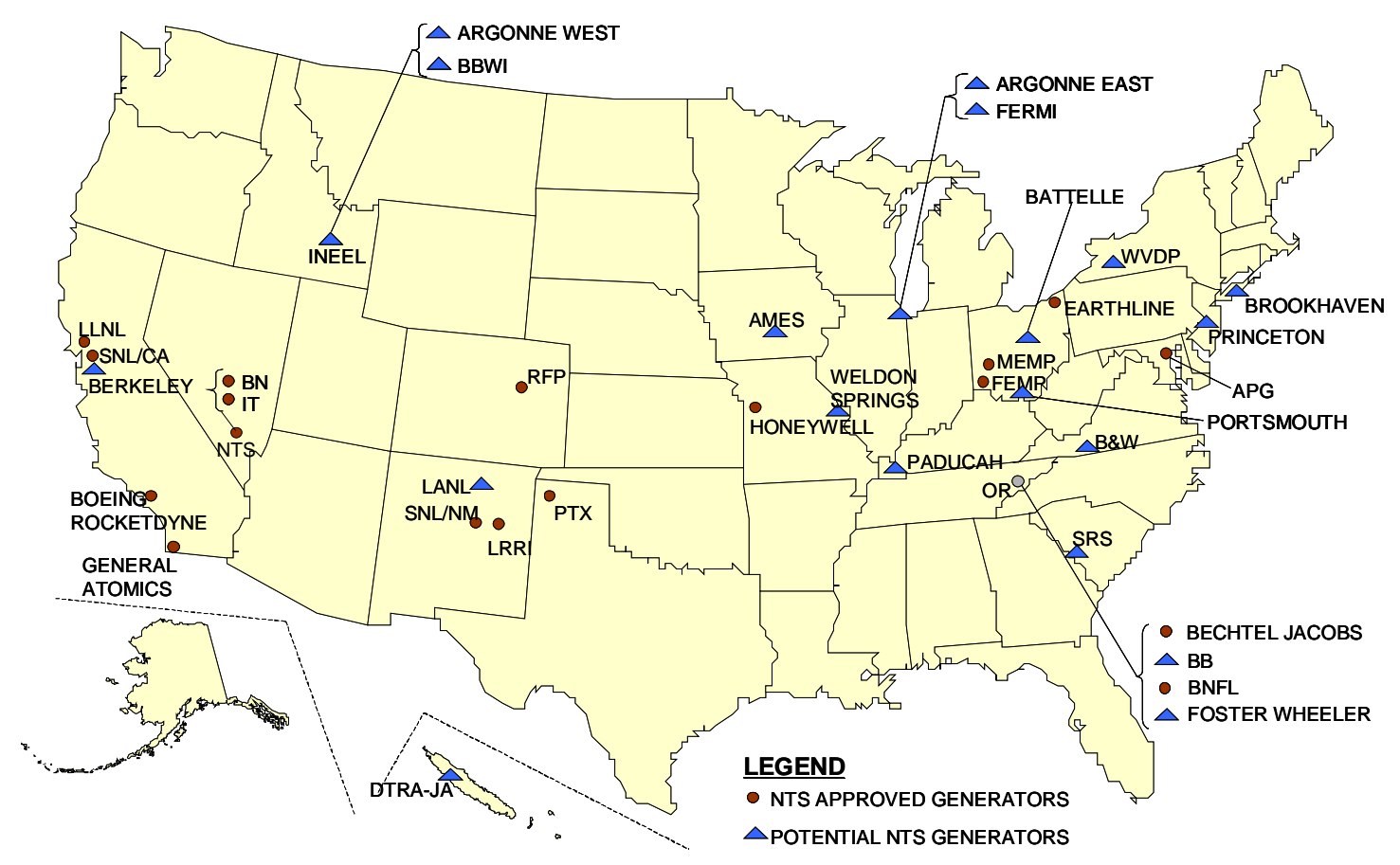


NNSA/NV EM will complete the majority of its own risk reduction and accelerated activities by 2010 . The NTS will remain under federal control in perpetuity as an NNSA test site, and the large buffer zone surrounding the NTS (the Nevada Test and Training Range) is assumed to remain under the control of the U.S. Air Force. There are no plans for transfer of any NTS lands to other agencies or public entities. Access will continue to be restricted to the NTS and the surrounding areas.

\section{For management purposes, NNSA/NV EM} activities have been established based on the source of contamination and type of waste requiring management. Environmental Restoration activities within the State of Nevada fall under the purview of a formal regulatory agreement, the Federal Facility Agreement and Consent Order (FFACO); Environmental Restoration activities outside the State of Nevada fall under the purview of each affected State's regulatory framework but are planned and negotiated with the State using the FFACO Corrective Action Strategy framework for applicable activities. Waste Management activities are governed by the Federal Facility Compliance Act and Consent Order (FFCAct) and the Mutual Consent Agreement (MCA). A Joint Low-Level Waste Oversight Agreement is in place to allow State of Nevada representatives to participate in review and approval processes associated with waste receipt and disposal operations.

\section{Key Agreements}

These agreements include:

- Federal Facility Agreement and Consent Order. An agreement and consent order between DOE, the State of Nevada, and DoD on environmental restoration activities. The State regulator continues to provide proactive support of the agreement and has worked cooperatively with NNSA/NV EM to clearly define expectations, streamline documentation requirements, actively support data quality objective processes, expedite approval processes, and avoid barriers to project activities.

- Renegotiation of the UGTA Corrective Action Strategy will allow UGTA activities to proceed with a more clearly defined pathway to the end state.

- Negotiation of a 1,000 pCi/g soils corrective action level will result in a significant cost avoidance for Soils corrective actions.

- Federal Facility Compliance Act. The Federal Facility Compliance Act of 1992 (FFCAct) required the Secretary of Energy to create and submit Site Treatment Plans for the development of treatment capacity and technologies for mixed wastes. In accordance with the FFCAct, $\mathrm{DOE} / \mathrm{NV}$ and the State of Nevada signed an FFCAct and Consent Order in March 1996. The signed consent order mandated treatment schedules for NTS legacy mixed waste inventories, identified in the NTS Site Treatment Plan.

- Mutual Consent Agreement. A Mutual Consent Agreement (MCA) has been established by DOE/NV and the State of Nevada, allowing available storage capacity on the TRU Pad to be used for the storage of on-site generated MLLW that does not meet RCRA Land Disposal Restriction (LDR) provisions. It was originally established in January 1994 and was updated in June 1995 to incorporate the handling of MLLW generated by DOE/NV activities within the State of Nevada that are not currently identified in the Site Treatment Plan. The changes also provided DOE/NV with a nine-month period to prepare and submit a plan for the treatment and disposal of such wastes.

- Joint Low-Level Waste Oversight Agreement. An agreement with the State of Nevada to allow joint oversight of the low-level radioactive waste program. State representatives participate in the review and approval process to ensure waste intended for disposal at the NTS conforms to requirements of the NTS Waste Acceptance Criteria. 
NNSA/NV EM activities resulting from the historical nuclear testing activities are comprised of the following:

Industrial Sites - Industrial Sites are potentially contaminated surface and near-subsurface areas impacted by testing activities conducted on the NTS and Tonopah Test Range. The types of sites include leachfields, sumps, disposal wells, tanks, contaminated waste piles, ordnance sites, chemical storage areas, etc. Contaminants may include various combinations of hazardous organic and inorganic chemicals, unexploded ordnance, petroleum hydrocarbons, and low-level radionuclides. Potential risks associated with contamination at these sites and facilities are to workers and the environment.

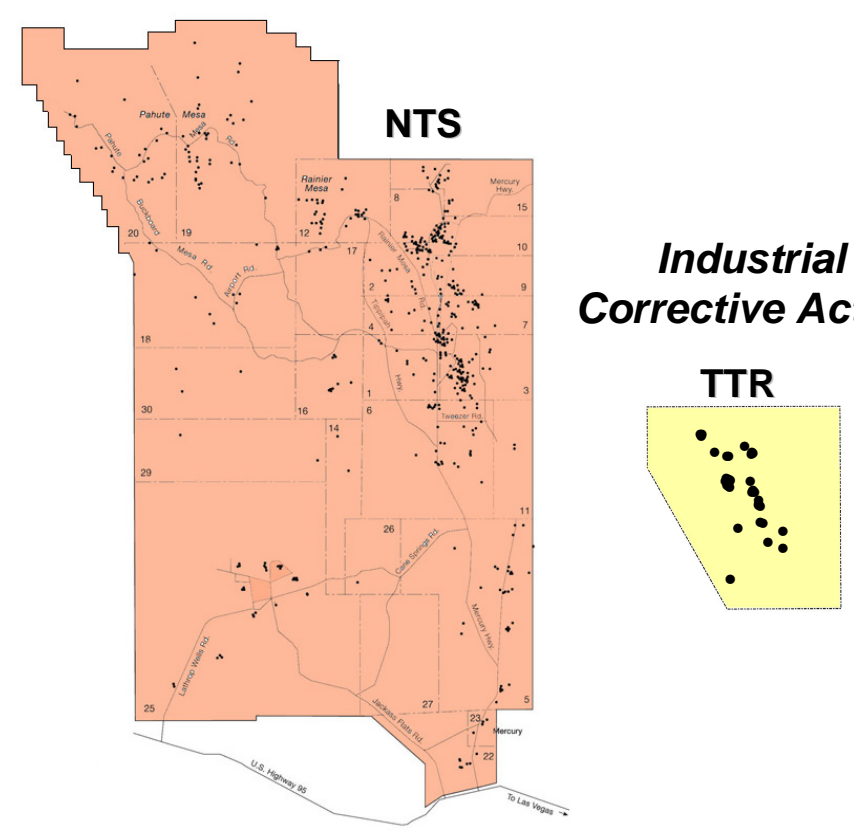

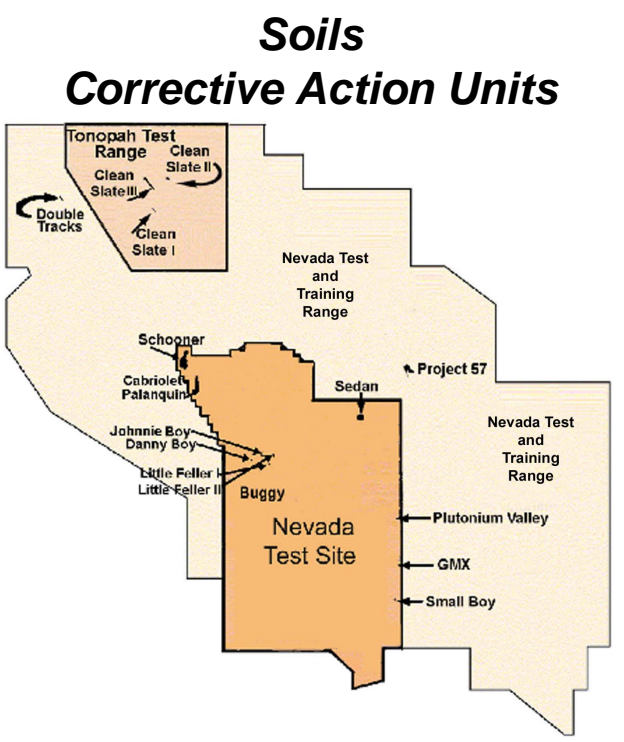

Soils - Soils activities are comprised of all sites on the NTS, Tonopah Test Range, and the Nevada Test and Training Range where historic atmospheric and aboveground safety tests were conducted. Contaminants of concern include transuranics and uranium, as well as fission and fusion products; metals, particularly lead, and other contaminants associated with the instrumentation and structures specific for each test. Risk associated with the sites on the ranges is due to institutional control being outside the control of NNSA/NV. In addition, not all of the Soils activities have been characterized to a level so that a corrective action alternative and an as-low-asreasonably-achievable (ALARA) analysis can be performed. Until the off-NTS Soils sites are remediated, there are risks to U.S. Air Force personnel, the public (inadvertent intruders), and the environment. 
UGTA Corrective Action Units

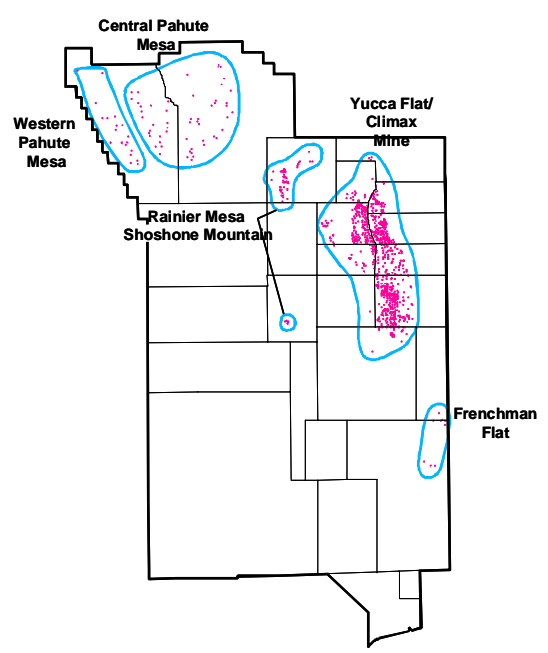

Underground Test Area - These activities, which are grouped into five corrective action units, include all former sites at the NTS where underground nuclear testing occurred, many in or below the water table. This testing resulted in over 300 million curies of radioactivity in the subsurface of the NTS. Tritium is the primary contaminant of concern because of its mobility and abundance. Risks associated with the subsurface contamination are to the groundwater both on and off the NTS. Closure-in-place with monitoring is considered to be the only feasible corrective action because cost-effective groundwater technologies have not been developed to effectively remove or stabilize subsurface contaminants. Risk is to workers, the public, and the environment. The UGTA activities are the highest priority with the State regulator due to the limited availability of water resources within the State.

Offsites - Activities are comprised of all corrective actions required at nine sites in five states where historic underground nuclear test were conducted. Contaminants of potential concern are hydrocarbons, metals, and radionuclides in the surface and radionuclides resulting from the underground nuclear detonations in the subsurface. Risks primarily associated with the surface are a result of unrestricted public access to the sites. In order to control risks associated with the subsurface contamination, there is a need to maintain institutional control and restrict access to the contamination associated with the shot cavity. Closure-in-place is considered the only feasible corrective action for the subsurface because cost-effective technologies have not

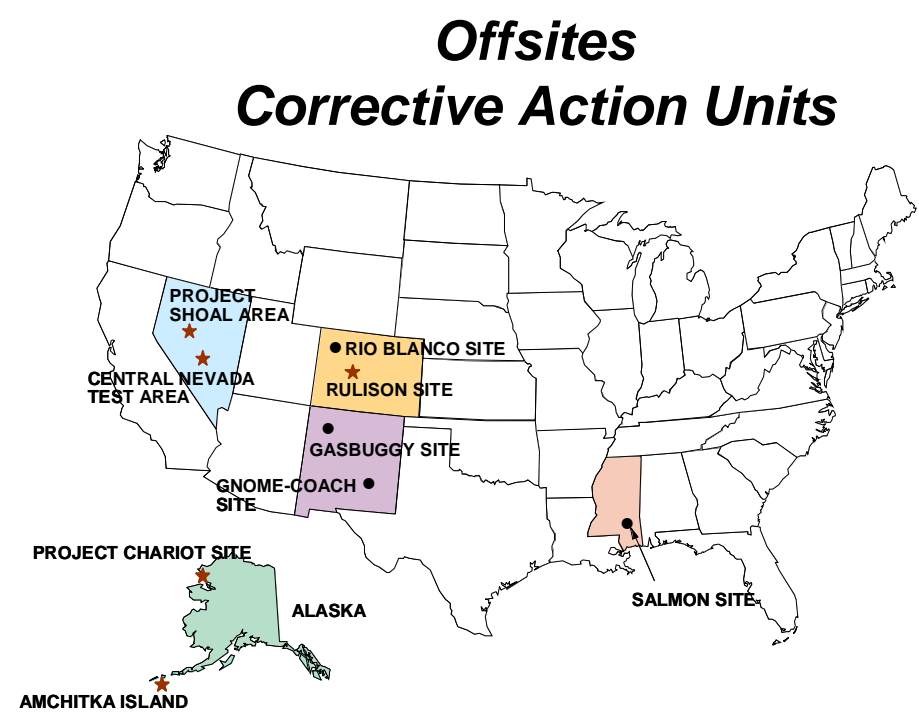
been developed to effectively remove or stabilize the contaminants. Risk is to workers, the public, and the environment.

$\boldsymbol{T R U}$ - TRU activities address the approximately 23,730 cubic feet legacy TRU waste in storage at the NTS that requires characterization and preparation of the waste for shipment to the Waste Isolation Pilot Plant (WIPP) and development of a path forward for TRU waste packaged in oversize containers, classified material, and spheres in storage with no path forward for disposition. Contaminants of concern are transuranic radionuclides. Risks associated with the activities are maintaining compliant storage 
configurations, processing of waste for disposal, and transportation of the waste to WIPP for disposal. Risk is to workers and the environment.

\section{Waste Management}

Operations - Activities

include those actions required to ensure LLW and MLLW disposal capability is maintained in a cost-effective, efficient, safe manner and available for use by the DOE complex. Contaminants of concern are a broad array of hazardous and radionuclide constituents. Risks associated with the activities are primarily associated with disposal operations. Risk is to workers and the environment.

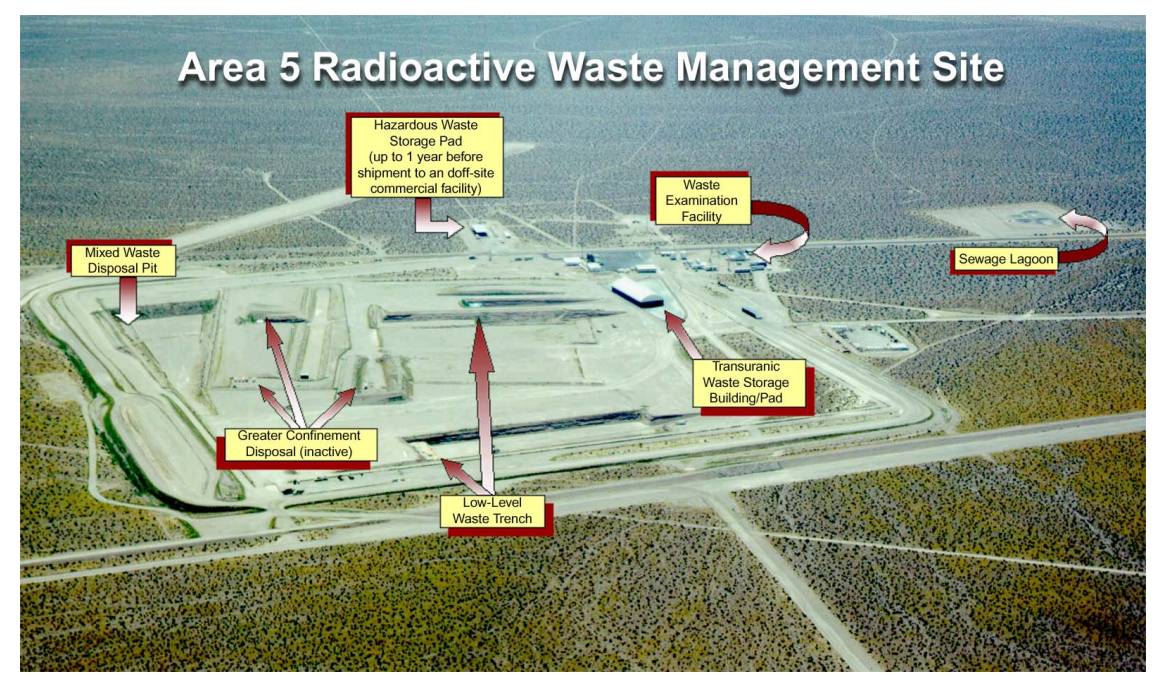

\section{In Summary}

Significant progress has been made by NNSA/NV EM in supporting the DOE complex cleanup activities. The NTS has historically, and continues to, receive a major portion of the low-level waste shipped for disposal from other DOE sites and remains a cost-effective option for low-level waste disposal in the complex. The NTS is ready to receive mixed low-level waste from off-site generators as soon as the State of Nevada approves a Resource Conservation and Recovery Act (RCRA) Part B Permit for this activity. Focus on restoration activities has resulted in the cleanup of well over half of the Industrial Sites locations to date; the UGTA corrective action strategy has been renegotiated with the State of Nevada and has been peer-reviewed and validated by a prestigious panel of experts in their respective fields of experience; a Soils corrective action level has been tentatively negotiated with the U.S. Air Force and the State regulator at a substantially less-restrictive number than previously desired by the parties; and surface work at six of the Offsites locations has been completed.

For efficiency and effectiveness, and to keep the focus on the end state for NNSA/NV EM activities, NNSA/NV EM activities could be treated as a single project with defined milestones and performance measures. In addition, with the cooperation of its contractors, regulators, and stakeholders, NNSA/NV EM will accelerate risk reduction activities to minimize risk to workers, the public, and the environment. Activities will be conducted in compliance with all applicable laws and regulations; requirements, principles, and practices associated with Integrated Safety Management; and sound project management.

This plan will be a living document and updated to address changing conditions as they occur. NNSA/NV EM is committed to achieving the objectives and strategies contained within this plan and will re-evaluate options, strategies, approaches, methods, and alternative technologies as opportunities become available to further streamline activities. 


\subsection{Accelerated Cleanup Strategy}

Acceleration of NNSA/NV EM activities and maintaining waste disposal capability for DOE complex-wide waste generators requires a commitment to six strategic initiatives. Table 1 summarizes the initiatives.

\section{Table 1: Strategic Initiative and Major Activities}

\begin{tabular}{|c|c|c|c|}
\hline Strategic Initiatives & $\begin{array}{l}\text { Key Change in } \\
\text { Cleanup Approach }\end{array}$ & Major Activity & Planned Strategy/Path Forward \\
\hline $\begin{array}{l}\text { Strategic Initiative } 1 \\
\text { Accelerate the cleanup of } \\
\text { contaminated Industrial Sites }\end{array}$ & $\begin{array}{l}\text { Aggregate sites into larger, } \\
\text { more efficient corrective } \\
\text { action units }\end{array}$ & $\begin{array}{l}\text { Industrial Sites - Clean- } \\
\text { close or close-in-place } \\
\text { contaminated areas under } \\
\text { the Federal Facility } \\
\text { Agreement and Consent } \\
\text { Order. }\end{array}$ & $\begin{array}{l}\text { Characterize the site, determine an acceptable closure } \\
\text { strategy, employ the strategy, gain closure concurrence } \\
\text { from the State of Nevada, and establish institutional } \\
\text { controls and monitor as applicable for the areas with } \\
\text { residual close-in-place contamination obtaining } \\
\text { efficiencies by aggregating sites. }\end{array}$ \\
\hline \multirow[t]{2}{*}{$\begin{array}{l}\text { Strategic Initiative } 2 \\
\text { Accelerate Soils corrective } \\
\text { actions by establishing and } \\
\text { implementing a Soils } \\
\text { corrective action level of } \\
1,000 \mathrm{pCi} / \mathrm{g}\end{array}$} & \multirow[t]{2}{*}{$\begin{array}{l}\text { Clean sites up to } 1,000 \mathrm{pCi} / \mathrm{g} \\
\text { rather than } 400 \mathrm{pCi} / \mathrm{g}\end{array}$} & $\begin{array}{l}\text { Soils - Remove } \\
\text { contaminated soil from } \\
\text { locations off the NTS under } \\
\text { the Federal Facility } \\
\text { Agreement and Consent } \\
\text { Order. }\end{array}$ & $\begin{array}{l}\text { Establish a } 1,000 \mathrm{pCi} / \mathrm{g} \text { corrective action level, } \\
\text { characterize the site, remove contaminated soil as } \\
\text { appropriate, monitor as appropriate, and gain closure } \\
\text { concurrence from the State of Nevada and the } \\
\text { U.S. Air Force. }\end{array}$ \\
\hline & & $\begin{array}{l}\text { Soils - Close in place } \\
\text { contaminated soil within } \\
\text { the NTS boundaries under } \\
\text { the Federal Facility } \\
\text { Agreement and Consent } \\
\text { Order. }\end{array}$ & $\begin{array}{l}\text { Characterize the site, determine an acceptable closure } \\
\text { strategy, employ the strategy, gain closure concurrence } \\
\text { from the State of Nevada, and establish institutional } \\
\text { controls for the areas with residual close-in-place } \\
\text { contamination. }\end{array}$ \\
\hline \multirow{2}{*}{$\begin{array}{l}\text { Strategic Initiative } 3 \\
\text { Manage future risk to the } \\
\text { public from contaminated } \\
\text { groundwater by predicting } \\
\text { contaminant boundaries }\end{array}$} & \multirow{2}{*}{$\begin{array}{l}\text { Earlier involvement of State } \\
\text { regulator in activities } \\
\text { to enhance acceptance of } \\
\text { models and other products }\end{array}$} & $\begin{array}{l}\text { UGTA - Establish } \\
\text { corrective action } \\
\text { contaminant boundaries. }\end{array}$ & $\begin{array}{l}\text { Drill characterization wells, characterize hydrology, } \\
\text { determine transport parameters, and develop flow and } \\
\text { transport models. }\end{array}$ \\
\hline & & $\begin{array}{l}\text { UGTA - Establish } \\
\text { monitoring network. }\end{array}$ & $\begin{array}{l}\text { Establish monitoring wells, conduct sampling to ensure } \\
\text { protection of the public and environment, and establish } \\
\text { institutional controls for the areas with residual } \\
\text { close-in-place contamination. }\end{array}$ \\
\hline \multirow[t]{2}{*}{$\begin{array}{l}\text { Strateqic Initiative } 4 \\
\text { Negotiate strategies for } \\
\text { corrective actions in other } \\
\text { states similar to successful } \\
\text { strategies used in the State of } \\
\text { Nevada }\end{array}$} & \multirow[t]{2}{*}{$\begin{array}{l}\text { Earlier involvement of State } \\
\text { regulator in activities } \\
\text { to enhance acceptance of } \\
\text { models and other products }\end{array}$} & $\begin{array}{l}\text { Offsites - Close the surface } \\
\text { areas at all the Offsites } \\
\text { locations. }\end{array}$ & $\begin{array}{l}\text { Negotiate with respective State regulators and other } \\
\text { agency representatives, determine an acceptable } \\
\text { closure strategy, employ the strategy, gain closure } \\
\text { concurrence from the respective states, and establish } \\
\text { institutional controls for the areas with residual } \\
\text { close-in-place contamination. }\end{array}$ \\
\hline & & $\begin{array}{l}\text { Offsites - Establish } \\
\text { contaminant boundaries. }\end{array}$ & $\begin{array}{l}\text { Characterize hydrology; determine transport } \\
\text { parameters; develop flow and transport models; conduct } \\
\text { well development, testing, and sampling; provide results; } \\
\text { and establish institutional controls; and monitor as } \\
\text { applicable for the areas with residual close-in-place } \\
\text { contamination. }\end{array}$ \\
\hline $\begin{array}{l}\text { Strategic Initiative } \mathbf{5} \\
\text { Accelerate the disposition of } \\
\text { TRU waste in storage at the } \\
\text { NTS }\end{array}$ & $\begin{array}{l}\text { Investigate new technology } \\
\text { for TRU with no path forward } \\
\text { for disposition }\end{array}$ & $\begin{array}{l}\text { TRU/Mixed TRU - } \\
\text { Disposition all EM } \\
\text { TRU/Mixed TRU currently } \\
\text { stored. }\end{array}$ & $\begin{array}{l}\text { Characterize, certify, and send legacy mixed TRU drums } \\
\text { to WIPP for disposal; obtain viable treatment method for } \\
\text { oversize and classified TRU/Mixed TRU; and dispose } \\
\text { after treatment. }\end{array}$ \\
\hline \multirow[t]{2}{*}{$\begin{array}{l}\text { Strategic Initiative } 6 \\
\text { Maintain cost-effective, } \\
\text { efficient, safe LLW and MLLW } \\
\text { disposal capability to meet the } \\
\text { needs of the DOE complex }\end{array}$} & \multirow[t]{2}{*}{$\begin{array}{l}\text { Evaluate opportunities for } \\
\text { further efficiencies in waste } \\
\text { operations }\end{array}$} & $\begin{array}{l}\text { Low-Level Waste - } \\
\text { Maintain capability to } \\
\text { dispose of LLW from on- } \\
\text { and off-site waste } \\
\text { generators. }\end{array}$ & $\begin{array}{l}\text { Maintain sufficient disposal capacity to meet the } \\
\text { complex disposal needs under CRA proposals, ensure } \\
\text { waste accepted for disposal meets criteria, and adhere } \\
\text { to requirements necessary to maintain disposal } \\
\text { authorization. }\end{array}$ \\
\hline & & $\begin{array}{l}\text { Mixed Low-Level Waste - } \\
\text { Maintain capability to } \\
\text { dispose of MLLW from on - } \\
\text { and off-site waste } \\
\text { generators. }\end{array}$ & $\begin{array}{l}\text { Secure RCRA Part B Permit for receipt of MLLW from } \\
\text { off-site generators. Maintain sufficient disposal capacity, } \\
\text { ensure waste accepted for disposal meets criteria, and } \\
\text { adhere to requirements necessary to maintain disposal } \\
\text { authorization and those in the RCRA Part B Permit } \\
\text { (permit planned to be obtained in FY 2003). }\end{array}$ \\
\hline
\end{tabular}

Under Cleanup Reform Account (CRA) Funding, significant acceleration is accomplished for Industrial Sites (9 years), Soils (16 years), and TRU ( 2 years) 
Table 2 provides the anticipated effects on projected end dates resulting from Cleanup Reform Account Funding.

Table 2: Cleanup Reform Account (CRA) Funding Effects on Projected End Dates

\begin{tabular}{|l|c|c|}
\multicolumn{1}{|c|}{$\begin{array}{c}\text { NNSA/NV } \\
\text { Environmental Management Project }\end{array}$} & $\begin{array}{c}\text { Non-CRA Funding } \\
\text { End Date }\end{array}$ & CRA Proposed End Date \\
\hline Industrial Sites Project & 2017 & 2008 \\
\hline Soils Project & 2026 & 2027 \\
\hline Underground Test Area Project * & 2032 & 2014 \\
\hline Offsites Project * & 2015 & 2007 \\
\hline TRU/Mixed TRU Project & 2009 & 2021 ** \\
\hline Waste Management Operations & $2021^{* *}$ & \\
\hline
\end{tabular}

* Five-year Proof-of-Concept required to validate contaminant boundary models limit acceleration opportunities

** Operations transfer to NNSA at this time

\section{Strategic Initiative 1: Accelerate the Cleanup of Contaminated Industrial Sites}

\section{STRATEGY:}

Key Change in Cleanup Approach: Aggregate sites into larger, more efficient corrective action units.

Sites on the Tonopah Test Range will be addressed first because access and institutional controls are the responsibility of the U.S. Air Force; sites on the NTS will be remediated starting in the southwest corner of the NTS in accordance with future land use planning. The most contaminated sites will be addressed first. Limited site remediation will be conducted during the site assessment phase, as appropriate, to achieve early closure. Remediation, stabilization, control of contamination, and monitoring, as appropriate, will occur at multiple sites in parallel. Sites will be aggregated into larger corrective action units to achieve more efficient cleanup resulting from fewer required regulatory documents, co-location of sites, commonality of source contamination and required regulatory actions, and better utilization of craft personnel.

END STATE: Applicable corrective actions will be completed for all 1,047 sites, and most sites will be open for free, unrestricted use while others will be stabilized for restricted use appropriate to the risk posed by residual contamination. For those sites where contamination remains in place, appropriate long-term stewardship activities will be in place, including monitoring, cap inspections, and use restrictions as applicable to the site.

\section{Benefits}

- Completes closure of all sites by 2008

- Reduces potential liabilities from uncontrolled contamination

- Reduces exposure to workers and U.S. Air Force Personnel

- Reduces NNSA/NV liability for sites off the NTS

- Allows unrestricted use of land and facilities by NNSA/NV for existing and new missions 


\section{NEAR-TERM (FY 2003/2004) MILESTONES/METRICS:}

- Complete closure of 19 Rad Contamination Areas (09/2004).

- Complete closure of 12 Hazardous Waste Areas (09/2004).

- Complete closure of 19 Leachfield/Septic Systems (08/2004).

- Complete closure of 5 Landfills (09/2004).

- Complete closure of 21 Miscellaneous Areas such as ordnance, tanks, burn pits, etc (09/2004).

Strategic Initiative 2: Accelerate Soils Corrective Actions by Establishing and Implementing a Soils Corrective Action Level of 1,000 pCi/g

STRATEGY:

Key Change in Cleanup Approach: Clean sites up to $1,000 \mathrm{pCi} / \mathrm{g}$ rather than $400 \mathrm{pCi} / \mathrm{g}$.

A tentatively negotiated corrective action level of $1,000 \mathrm{pCi} / \mathrm{g}$ will be formalized with the U.S. Air Force to address sites off the NTS, which will be remediated first because access and institutional controls are the responsibility of the U.S. Air Force. The negotiated corrective action level will be based on computer analysis of residual radiation and ALARA determinations. Confirmatory sampling of cleanup results will be done in conjunction with the U.S. Air Force. Sites on the NTS will be characterized, hot spots removed as required to prevent risk to workers, and use restrictions applied.

END STATE: Sites off the NTS will be cleaned up to $1,000 \mathrm{pCi} / \mathrm{g}$ and formally closed, and site control relinquished to the U.S. Air Force. Sites on the NTS will be characterized; hot spots removed, fenced, posted, and monitored as applicable and relinquished to NNSA/NV restricted access.

\section{NEAR-TERM (FY 2003/2004) MILESTONES/METRICS:}

\section{Benefits}

- Completes Soils activities by 2010

- Reduces NNSA/NV liability for sites off the NTS

- Reduces risk to U.S. Air Force personnel and NTS workers

- Limits potential for inadvertent exposure

- Allows restricted use of lands by the U.S. Air Force and NNSA/NV

- Obtain formal concurrence on and institutionalize a corrective action level of $1,000 \mathrm{pCi} / \mathrm{g}(09 / 2003)$.

- Complete formal closure of interim action sites (Double Tracks and Clean Slates 1) (09/2004).

Strategic Initiative 3: Manage Future Risk to the Public From Contaminated Groundwater by Predicting Contaminant Boundaries

STRATEGY:

Key Change in Cleanup Approach: Earlier involvement of State regulator in activities to enhance acceptance of models and other products.

The recently renegotiated UGTA corrective action strategy will be implemented. Data collection will occur in Phase 1 to fill data gaps and reduce uncertainty with additional data 
to be collected in Phase 2, if needed. Data will allow evaluation of contaminant transport to predict future extent of contaminant movement so that groundwater flow and transport models can be developed to predict contaminant boundaries. Independent peer reviews will be conducted to assess the technical aspects of groundwater models, and the predictive models will be validated. Regulator and stakeholder involvement will be increased throughout the process to ensure better understanding of the steps in reaching a contaminant boundary for each group of sites.

END STATE: A contaminant boundary will be established to define areas that contain water that may be unsafe for domestic and municipal use. A monitoring network will be in place to ensure future protection of the public and the environment. Institutional controls will be continued, and wells will be monitored, sampled, and refurbished/replaced as applicable.

\begin{tabular}{|l|}
\hline \multicolumn{1}{|c|}{ Benefits } \\
- Provides greater understanding of the risks \\
associated with groundwater contamination \\
- Manages risk to off-site receptors \\
- Increases confidence in models \\
Reduces uncertainty associated with predicted \\
volumes of contaminated groundwater \\
associated with possible National Resources \\
Damage Assessment (NRDA) claims \\
\hline
\end{tabular}

\section{NEAR-TERM (FY 2003/2004) MILESTONES/METRICS:}

- Complete Pahute Mesa Phase I Hydrology Data Analysis (05/2003).

- Drill Four Wells in Yucca Flat (09/2003).

- Complete Rainier Mesa Value of Information Analysis (VOIA) (09/2004).

- Complete Frenchman Flat Phase I Source Term Data Analysis (09/2004).

- Complete Yucca Flat Phase I Well Development and Testing (08/2004).

- Complete Pahute Mesa Phase I Source Term Analysis (03/2004).

\section{Strategic Initiative 4: Negotiate Strategies for Corrective Actions in Other States Similar to Successful Strategies Used in the State of Nevada}

STRATEGY:

Key Change in Cleanup Approach: Earlier involvement of State regulator in activities to enhance acceptance of models and other products.

NNSA/NV EM will partner with other States' regulatory authorities to tailor closure strategies. Lessons learned from each additional state will be incorporated to update the strategies as applicable. Risk-based assessments will be used to develop surface and subsurface closure strategies. Surface areas will be closed first because of the lack of institutional control and accessibility of the sites to the public. The subsurface will be modeled to establish a contaminant boundary.

END STATE: The surface area of each site will be relinquished for unrestricted use to the individual landholder specific to the site; NNSA/NV will retain responsibility for the subsurface. Contaminant boundaries will be established for the subsurface, and appropriate long-term stewardship activities will be in place, including monitoring, cap inspections, and use restrictions, as applicable.

\section{Benefits}

- Completes all surface closures by 2006

- Establishes site-specific institutional controls for surface and subsurface

- Reduces potential for inadvertent exposure to the public

- Allows release of the surface for alternative uses by the landholders 
NEAR-TERM (FY 2003/2004) MILESTONE/METRICS:

- Complete Gnome-Coach surface decision document (07/2003).

- Complete radiological risk and gas reservoir analysis for the Rio Blanco subsurface (09/2003).

- Complete Central Nevada Test Area subsurface monitoring wells (06/2004).

- Complete Rio Blanco surface field remediation work (09/2004).

\section{Strategic Initiative 5: Accelerate the Disposition of TRU Waste in Storage at the NTS}

STRATEGY:

Key Change in Cleanup Approach: Investigate new technology for TRU with no path forward for disposition.

Nuclear safety authorization basis documents will be streamlined, and mobile vendors will be used for characterization and certification of TRU. Technologies will be investigated to determine a potential alternative for TRU materials/waste in storage with no path forward for disposition. If the proposed treatment for NTS legacy TRU is unsuccessful, the Western Small Quantity Site Acceleration Program identified in the WIPP Performance Management Plan will be the alternative path forward.

END STATE: TRU waste in legacy drums will be shipped to WIPP for disposal. TRU waste with no current path forward for disposition will have a new technology implemented, all oversized, classified, and spherical TRU materials/waste will be treated and the resulting waste disposed as LLW. Facilities will have been decontaminated and transitioned to other uses.

NEAR-TERM (FY 2003/2004) MILESTONES/METRICS:

Benefits
- Accelerates completion of disposition of TRU
materials/waste to 2007
- Reduces costs of characterization/certification
activities
- Develops an alternative for TRU
materials/waste with no path forward for
disposition
- Reduces risk to workers and the environment
- Eliminates classified materials from storage

- Complete development of safety authorization basis documents (09/2004).

- Initiate shipment of legacy TRU drums to WIPP (09/2003).

- Initiate investigation of new technology for TRU materials/waste with no path forward for disposition (01/2004).

Strategic Initiative 6: Maintain Cost-Effective, Efficient, Safe LLW and MLLW Disposal Capability to Meet the Needs of the DOE Complex

STRATEGY:

Key Change in Cleanup Approach: Evaluate opportunities for further efficiencies in waste operations.

Waste management operations will be maintained and operated in accordance with all requirements, including their safety authorization basis. NNSA/NV EM will ensure Waste Acceptance Criteria are efficient, effective, and regulatory-based to protect human health and environmental safety. The Performance Assessment/Composite Analysis data will be 
maintained to ensure the site remains compliant with its Disposal Authorization Statement. State comments on the RCRA Part B Permit that will allow receipt of MLLW from off-site generators will be proactively addressed. NNSA/NV EM will continue to seek funding as committed to by the Department during Waste Management Programmatic Environmental Impact Statement discussions.

END STATE: Disposal cells that have reached their capacity will be closed prior to transfer of the facilities to NNSA/NV in 2021 (when most of the complex's EM waste has been disposed). Closures and long-term stewardship obligations such as monitoring will be implemented in accordance

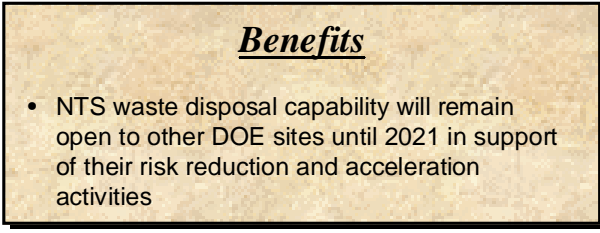

with regulatory requirements to ensure there is no risk to workers, the public, and the environment as the result of disposed waste.

\section{NEAR-TERM (FY 2003/2004) MILESTONES/METRICS:}

- Maintain capability to dispose waste volumes identified in formal waste generator forecasts provided to NNSA/NV EM annually (09/2003).

\section{Strategic Initiatives Prioritization:}

\section{Risk Reduction Priorities}

NNSA/NV EM risk reduction priorities are based on the needs of the DOE complex as well as the relative risk associated with NNSA/NV activities. Priorities for the NNSA/NV EM strategic initiatives are:

1) Waste Operations

2) Soils

3) TRU

4) Offsites

5) Industrial Sites

6) UGTA 


\section{BUSINESS STRATEGY}

\subsection{Management Roles and Responsibilities}

Key players in the implementation of this plan are the Assistant Secretary, Environmental Management; the Manager, NNSA/NV; the Assistant Manager, Environmental Management, NNSA/NV; the DOE Headquarters Nevada Site Team; the General Manager, M\&O contractor; and the Program Manager, A-E contractor. The roles and responsibilities of these individuals and organizations are described below:

The Administrator, NNSA. NNSA is responsible for ensuring that NNSA missions are properly planned and appropriate funding is requested from Congress to ensure successful completion of the national defense missions. In addition, the NNSA/NV Director of Engineering and Asset Management Division is responsible for ensuring the site infrastructure is properly maintained and appropriate support is provided to other missions.

Assistant Secretary, Environmental Management. The Assistant Secretary, Environmental Management, is responsible for ensuring that the NNSA/NV EM mission is properly planned and appropriate funding is requested from Congress to ensure successful completion of the NNSA/NV EM mission. In addition, EM-1 is responsible for ensuring proper stewardship planning has occurred prior to transition of sites where contamination remains in place. The sites will be transitioned to the landlord, NNSA/NV.

Manager, NNSA/NV. The Manager, NNSA/NV, is responsible for ensuring that appropriate support is provided to NNSA/NV EM to accomplish its mission. In addition, the NNSA/NV Manager's responsibilities include:

- Review status of the EM program on a bimonthly basis.

- Resolve issues and requirements that involve multiple programs/functions.

- Hold the Assistant Manager, Environmental Management, accountable for accomplishment of the scope, cost, schedule, and milestones within each activity's life-cycle baseline.

Assistant Manager, NNSA/NV EM. The responsibilities of Assistant Manager, Environmental Management, NNSA/NV include:

- Hold individual NNSA/NV EM project managers accountable for the scope, cost, schedule, and milestones within their applicable life-cycle baseline.

- Review progress on a monthly basis.

- Ensure that appropriate support is available, including appropriate health and safety, quality assurance, and project management processes and systems.

- Ensure appropriate contract mechanisms are in place, contractor performance is properly measured, and barriers to project success are removed.

- Maintain a positive, proactive, cooperative relationship with applicable regulators and stakeholders. 
- Report progress to DOE Headquarters as required by applicable systems and processes.

- Work with other DOE sites to ensure proper support is provided for generator waste disposal activities where waste is destined for disposal at the NTS.

DOE Headquarters EM Nevada Site Team. The EM Nevada Site Team reviews NNSA/NV EM activities on a weekly basis via teleconferencing; monthly through the NNSA/NV EM project control system; quarterly through the Project Execution Module; and twice a year via a formal review of all activities, successes, challenges, appropriate corrective actions, and lessons learned. Responsibilities include:

- Actively seek ways to assist in NNSA/NV EM activities, including generating new ideas and strategies to shorten the schedule or generate cost savings.

- Provide integration support for issues with other sites across the DOE complex.

- Ensure NNSA/NV EM activities are properly communicated to other entities within DOE.

- Monitor site performance.

- Participate in reviews of NNSA/NV EM planning, performance, and project control as well as technical and regulatory performance.

Contractor Managers. Contractor Managers are responsible for ensuring environmental restoration and waste management activities are conducted in accordance with NNSA/NV EM plans. Responsibilities include:

- Safely, efficiently, and effectively conduct assigned activities in accordance with the NNSA/NV EM life-cycle baselines and regulatory agreement requirements.

- Continually evaluate opportunities for acceleration of activities and increased efficiency and productivity.

- Monitor contract performance against NNSA/NV EM life-cycle baselines, including tracking, trending, and reporting programmatic and project performance through applicable systems and processes.

- Conduct all work in accordance with safety, environmental, and security requirements.

- Select and manage subcontractor work scope to achieve accelerated, cost-effective advancement of programmatic and project objectives.

- Resolve issues/conflicts and remove barriers to programmatic and project success.

- Maintain proactive, cooperative relationships with federal staff, regulators, and stakeholders. 


\subsection{Programmatic and Project Planning}

NNSA/NV EM is committed to implementation of strong project management principles and practices to ensure activities identified within this Plan have sound cost estimates, solid critical path schedules, and proper identification and management of risk and to ensure activities perform within the plan.

Life-Cycle Process

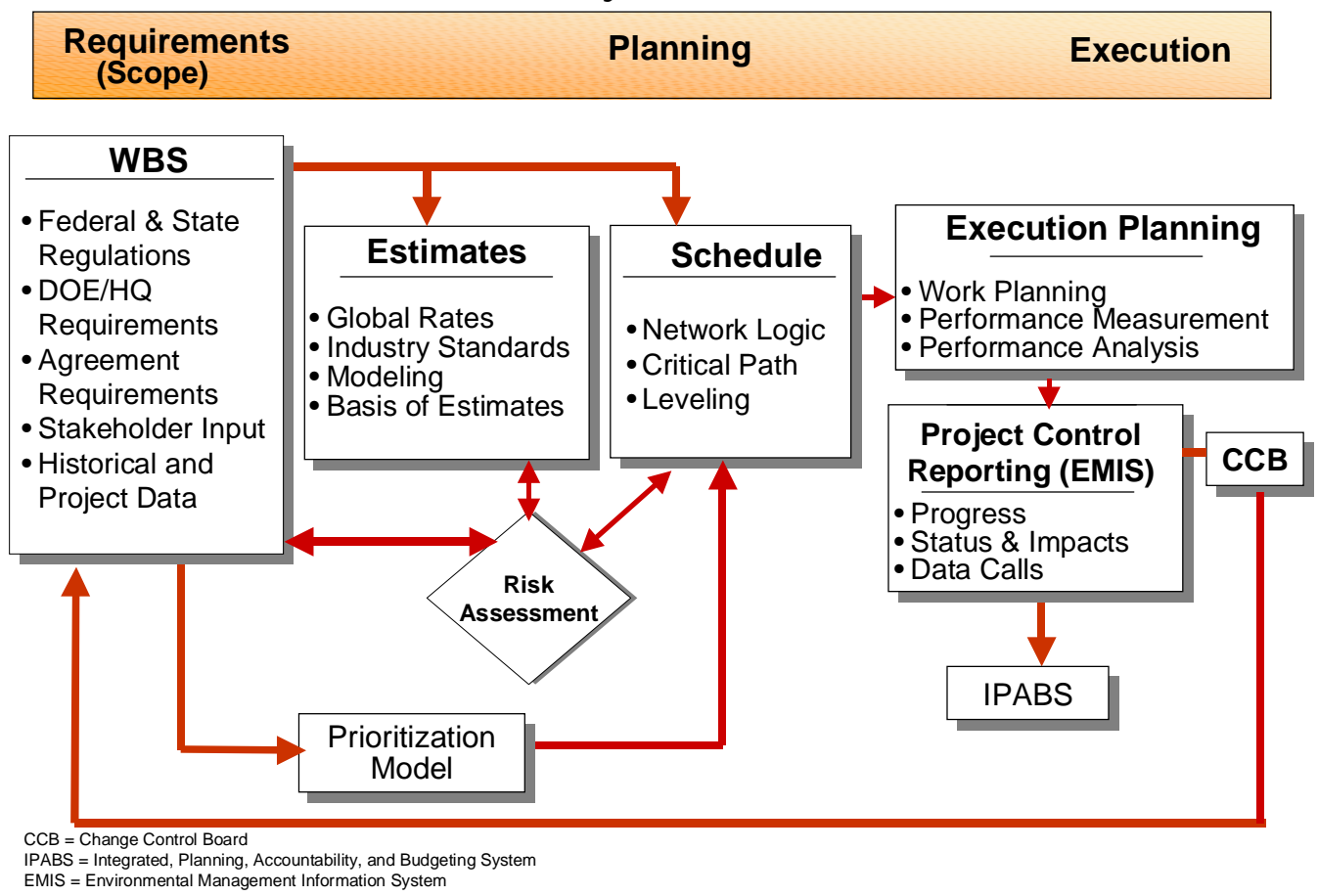

Life-Cycle Baselines. Each major activity is required to develop a life-cycle baseline in accordance with the principles and practices contained within DOE Order 430.1A, Life-Cycle Asset Management; DOE Policy 430.1, Land and Facility Use Planning (Joint Program Office Policy on Project Management in Support of DOE Order 430.1); DOE Order 413.3, Program and Project Management for the Acquisition of Capital Assets; and NNSA/NV EM procedures. Each life-cycle baseline is planned at successive levels of detail in accordance with the activity's work breakdown structure and dictionary; applicable regulatory requirements; and with activity-based, fully detailed and supported cost estimates; resource-loaded, critical-path schedules; and appropriate risk analysis performed. NNSA/NV EM life-cycle baselines are provided to regulators and stakeholders to ensure full communication regarding planned activities for the life of the NNSA/NV EM program.

Project Control System. NNSA/NV EM has developed a state-of-the-art project control system to ensure all activities are properly planned, evaluated, reported, trended, and configuration-managed. Use of the system is required for all NNSA/NV EM federal and contractor staff, and the system has been made available to the EM Nevada Site Team to ensure the team is fully apprised of NNSA/NV EM activities and performance against the plans for these activities. The system also is used to feed all applicable DOE Headquarters systems and processes. Electronic configuration management for change control actions is a 
key component within the system that allows all changes to scope, cost, schedule, and technical and regulatory requirements to be properly approved by the applicable threshold authority.

In order to ensure continued focus on project management principles and practices, NNSA/NV EM will continue to:

- Require federal staff to be actively involved in planning and be fully cognizant of the principles and practices of sound project management.

- Require adherence by its federal and contractor staff to the basic tenets of DOE Order 413.3 for all its activities.

- Require use of state-of-the-art project management tools to plan, estimate, schedule, evaluate, measure, control, and report progress.

- Support maintenance and enhancement of its project control system to ensure effective use of the system to manage, measure, control, and report project performance.

- Use appropriate resources to independently evaluate planning and performance data.

- Require senior management to regularly and actively review activities under their purview.

- Incentivize and evaluate contractor performance against baselines.

- Evaluate contractor performance on a monthly basis and regularly communicate with the contractor regarding issues/concerns/opportunities for acceleration of activities/lessons learned.

\subsection{Managing Risk and Uncertainty}

As with any program, there are sources of uncertainty and risk. The NNSA/NV EM program approach is to identify the sources of risk, understand the key components driving the uncertainty, and then implement controls and mitigation techniques to minimize adverse outcomes. The following assumptions are key to achieving the goals, objectives, strategies, and milestones identified in this Performance Management Plan:

- There will be no major changes to agency, federal, state, and local regulations and requirements that will impact identified activities.

- Environmental Restoration work will be conducted in accordance with FFACO requirements within the State of Nevada, and a similar strategy will be used in the other states where historic nuclear testing occurred.

- State regulators will not modify environmental restoration requirements to become more restrictive.

- The U.S. Air Force will proactively support completion of NNSA/NV EM activities on its lands.

- The U.S. Air Force and State regulator will allow soils corrective actions to proceed in accordance with the negotiated $1,000 \mathrm{pCi} / \mathrm{g}$ soils corrective action level.

- The Nevada State regulator will issue the RCRA Part B Permit for receipt of off-site generated MLLW in FY 2003.

- Currently forecasted volumes of waste destined for disposal at the NTS are accurate. 
- Waste generators will remain in compliance with the NTS Waste Acceptance Criteria and will ship waste in accordance with NNSA/NV EM agreements relative to transportation routing.

- Stakeholder issues and concerns will remain focused primarily on UGTA.

- Existing incentive contract types will remain in place.

- All work will be done safely, cost effectively, efficiently, and according to the baseline plan.

- It is assumed that there will be no excess facilities transferred to the program during the life-cycle of NNSA/NV EM.

\subsection{Managing Contracts}

NNSA/NV establishes performance-based incentives for its contractors to the maximum extent possible. The objectives of the performance-based fee provisions are to provide NNSA/NV with the mechanism to focus contractors on the achievement of highest-priority goals while not losing focus on other work scope. This also affords the contractor an opportunity to earn fee commensurate with their achievement of these specific NNSA/NV goals.

Performance metrics are assigned to projects based on the following considerations:

- Importance to NNSA's Environmental Management mission, the State of Nevada, and NNSA Headquarters

- Complexity of contractor scope (including the complexity of subcontractor participation)

- The level of contractor professional and managerial skill necessary to achieve the specified metric

The NNSA/NV federal staff are responsible for verifying and documenting scores that determine the fee for each discrete milestone for assigned activities. Included in the evaluation process is responsiveness and teamwork; management commitment; cost control; effectiveness of the planning, organization, and communications; quality and timeliness of products and services; and health and safety. Score cards are developed for each incentive milestone. These score cards are combined and factored into an equation which is used to determine the incentive fee to be awarded.

\subsection{Regulator and Stakeholder Interactions}

In order to accomplish the goals, objectives, strategies, and milestones contained within this Performance Management Plan, it is crucial that NNSA/NV EM continue positive, proactive relationships with State regulators and stakeholders. To ensure these relationships remain proactive and positive, NNSA/NV EM will continue to:

- Work closely with State regulators and stakeholders to ensure issues/concerns are addressed and to ensure the States and stakeholders are informed of NNSA/NV EM activities.

- Conduct its activities safely, efficiently, and costeffectively.

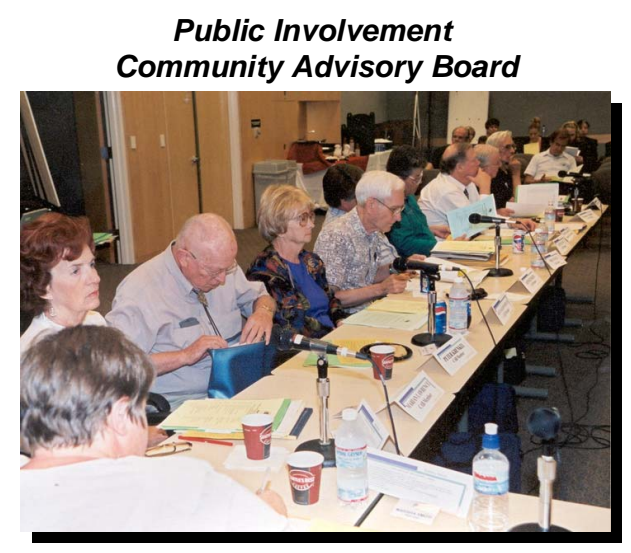


- Complete all regulatory-required milestones as planned.

- Meet regularly with State regulators and stakeholders to keep channels of communication open.

- Appropriately fund State regulators and appropriate stakeholder involvement initiatives.

- Require its federal and contractor staff to provide appropriate support of regulator and stakeholder initiatives. 


\subsection{Conclusion}

This Plan outlines NNSA/NV EM's strategy for completion of NNSA/NV EM activities. Although many NNSA/NV EM activities will be completed by 2010, NNSA/NV EM will maintain an active presence at the NTS because of its waste disposal mission for the DOE complex and environmental restoration activities associated with subsurface contamination. By 2029, all NNSA/NV EM activities will be completed and responsibilities for long-term stewardship turned over to the landlord, NNSA. Long-term stewardship planning is proceeding in accordance with Departmental initiatives, and regulators and stakeholders are involved in planning for the end state and long-term stewardship for project activities.

NNSA/NV EM is committed to executing this plan in accordance with all technical and regulatory requirements to achieve accelerated risk reduction and transition lands for future uses as applicable to the specific sites while maintaining waste disposal capability for the DOE complex. NNSA/NV EM is willing to be accountable for performance against the plan. In its previous historical activities, NNSA/NV has demonstrated strong performance to key national defense initiatives while conducting work safely, effectively, and efficiently. The resulting contaminated sites and facilities will be remediated in accordance with established regulatory commitments within the identified time frames. NNSA/NV EM will conduct its national waste disposal mission safely and with appropriate regulator and stakeholder involvement. Appropriate planning and mitigation strategies will be implemented to ensure proper stewardship of the remaining contaminated sites to ensure protection of workers, the public, and the environment, now and for future generations. 


\section{Appendix A}

Master Schedule 


\section{Master Schedule}

All U.S. Department of Energy National Nuclear Security Administration, Nevada Operations Office (NNSA/NV) Environmental Management activities have comprehensive life-cycle baseline plans. Each of the plans include logic driven ties between predecessor and successor activities to ensure connectivity throughout all phases of operations. Each of the activities is integrated to account for scope that is conducted by separate contractors. The sum of the respective and comprehensive activity plans equals the entire NNSA/NV Environmental Management Program.

The graphic on the next page illustrates the master schedule for all NNSA/NV Environmental Management activities. Logical connections are depicted where interface occurs between the respective aspects within the Environmental Management process. 
NNSA/NV EM 2010/2029 Schedule (Predecisional Draft)

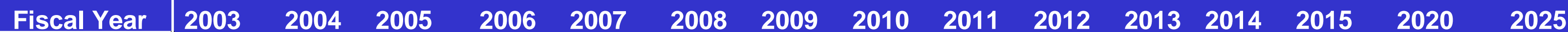

2030
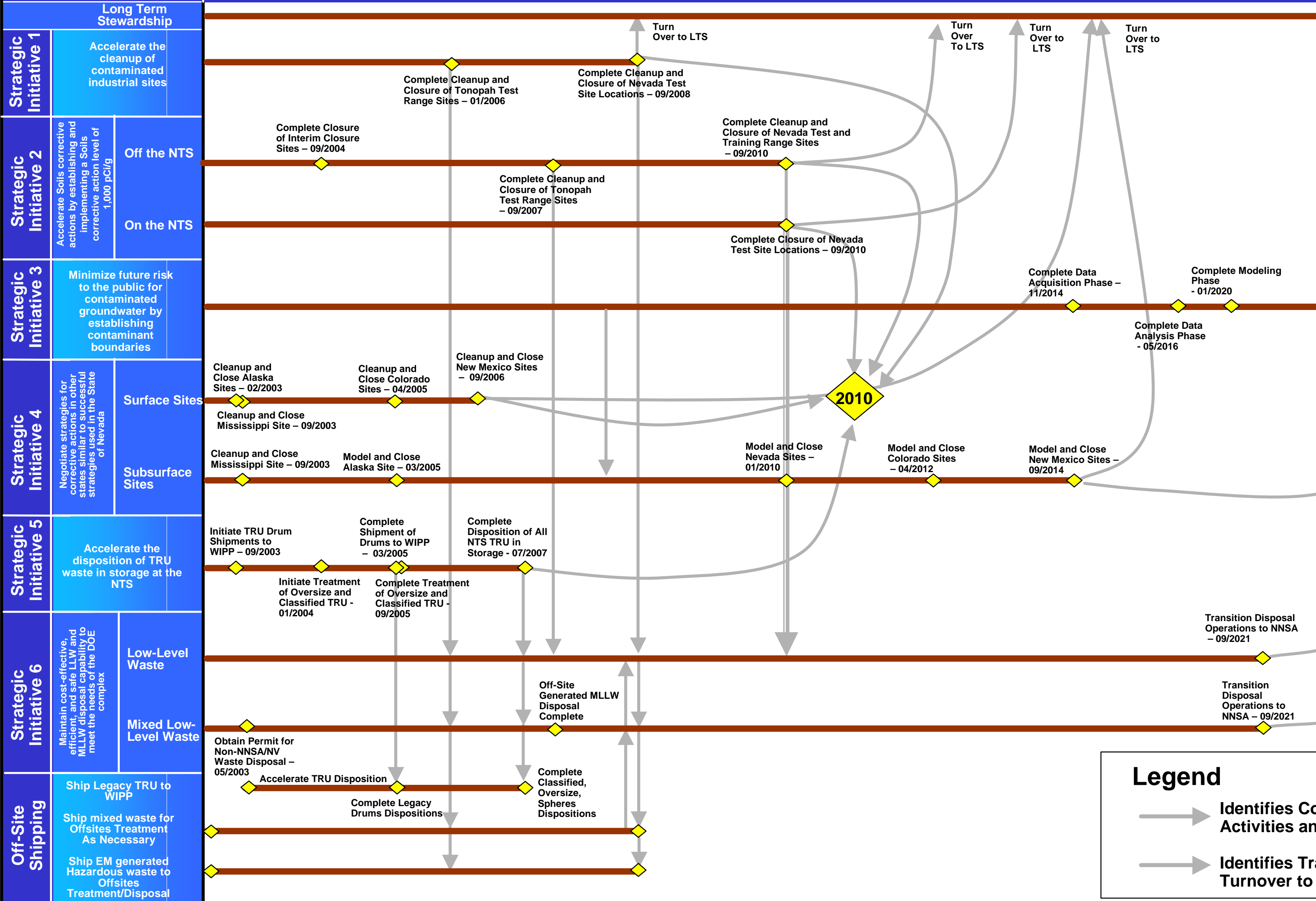

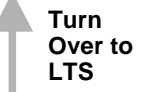

Complete Cleanup and
Closure of Nevada Test and
Training o Range Sites

Complete Closure of N Nevada
Test Site Locations -09201010

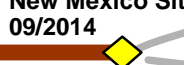

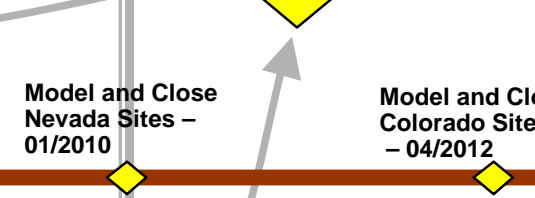
Transition Operations to
NNSA - 09/2021 Complete five-
year rorot
concept

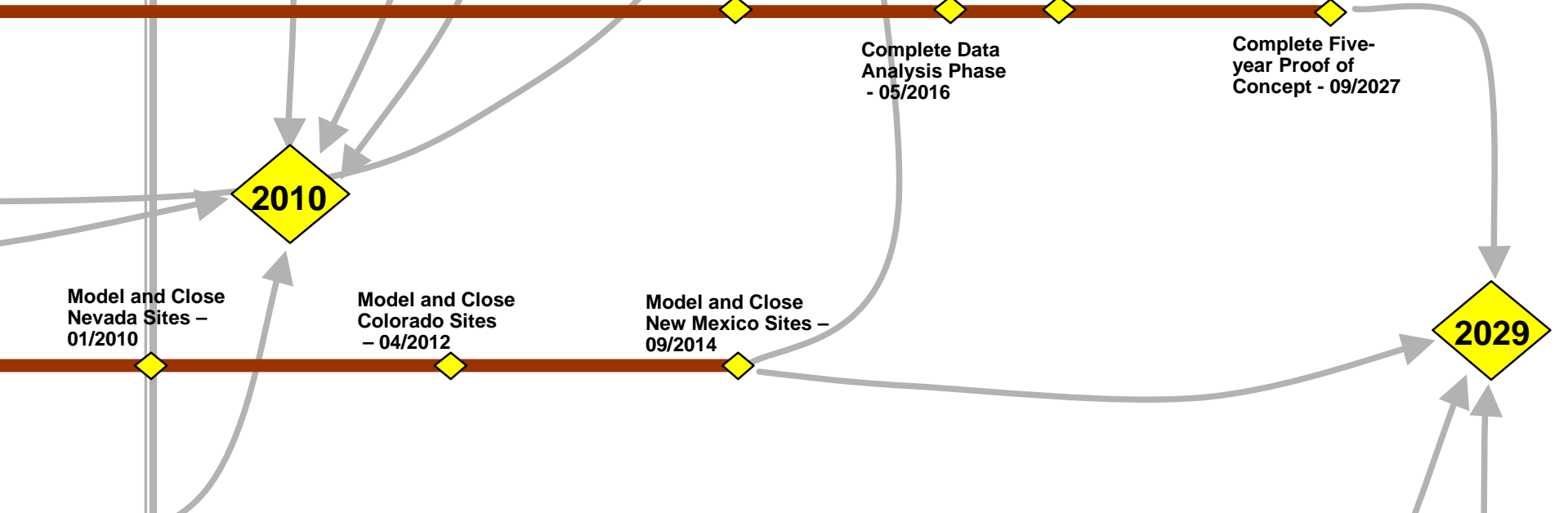


Appendix B

Challenges 


\section{Challenges}

While it will be extremely difficult to meet all the challenges contained within this plan, NNSA/NV EM will actively pursue initiatives to further accelerate its work. Among initiatives that will be evaluated are contract reform, further refinement of regulatory processes, and reevaluation of sequencing of work scope. 
Appendix C

Government Furnished Services 


\section{Government Furnished Services}

Government furnished services are fully integrated into life-cycle planning for NNSA/NV EM activities. The government furnished services are:

- Negotiate final Soils Corrective Action Level with U.S. Air Force and State regulator.

- Negotiate corrective action strategies for closure of sites in Alaska, Colorado, and New Mexico.

- Ensure TRUPACT IIs and approved shipping corridors are available to meet the acceleration goals of NNSA/NV EM TRU activities.

- Maintain ongoing, long-term waste disposal capability.

- Issue Safety Authorization Basis approvals per schedules.

- Complete recompete and award A-E contract.

NNSA/NV EM will actively work these respective issues with WIPP and the State of Nevada. NNSA/NV EM is not anticipating General Services Administration to provide any significant services or infrastructure beyond current standard equipment (e.g., vehicles). 
Appendix D

Letter of Intent 


\section{Letter of Intent}

Following this page is a Letter of Intent, dated May 13, 2002, between the State of Nevada Division of Environmental Protection and the U.S. Department of Energy, National Nuclear Security Administration Nevada Operations Office Environmental Management Program. The letter documents the commitment between the parties to accelerate major environmental management activities (except for the Underground Test Area activities) to achieve the completion of cleanup of the Nevada Test Site by 2010. The letter also identifies the principles under which this commitment will be executed. 


\section{LETTER OF INTENT}

May 13, 2002

\section{PURPOSE/VISION:}

This Letter of Intent documents a commitment by the State of Nevada, Division of Environmental Protection (NDEP) and the U.S. Department of Energy, National Nuclear Security Administration, Nevada Operations Office (NNSA/NV) Environmental Management (EM) program to accelerate its major environmental management project activities, with the exception of the Underground Test Area Project, to achieve fundamental cleanup completion of the Nevada Test Site by 2010 rather than 2020. Accelerated activities include Industrial Sites and Soils corrective actions required under the Federal Facility Agreement and Consent Order (FFACO); and the shipment of legacy transuranic waste to the Waste Isolation Pilot Plant (WIPP). Additionally, NNSA/NV EM and NDEP commit to implementation of the renegotiated strategy for the Underground Test Area and to explore further opportunities to accelerate UGTA activities. The parties also commit to continue to support the Department of Energy (DOE) Environmental Management (EM) mission of expedited cleanup. NNSA/NV EM will, operate its low-level waste and mixed-low-level waste disposal facilities for the DOE complex in compliance with all applicable Federal and/or State law(s). Additionally, this Letter documents previous agreements made by the Department with the State of Nevada and the NNSANV EM program as well as results of the Top-to-Bottom Review.

\section{PRINCIPLES:}

- $\quad$ NNSANV EM and its contractors will continue to ensure that all of their activities are conducted in accordance with Integrated Safety Management principles, compliant with applicable state and federal regulations, and are protective of human health and the environment. Risk reduction will be the primary focus of the program's activities.

- $\quad$ NNSANV EM and its contractors will take all necessary steps to accelerate cleanup activities and ensure these activities are properly funded. Acccelerated cleanup at the NTS will be focused on the following:

- Implementation of the previously negotiated acceleration of Industrial Sites corrective actions for a schedule acceleration of two years with cleanup anticipated to be completed in 2008 .

- Implementation of the recently renegotiated corrective action strategy regarding the Underground Test Area project and continue working with the state regulator and stakeholders to ensure project activities efficiently and effectively reflect the negotiated parameters.

- Acceleration of plutonium contaminated soils corrective actions by 10 years at the recently negotiated (with the Air Force) correction action levels of $1000 \mathrm{piC} / \mathrm{g}$ based on a military land use scenario and an exposure dose level of $25 \mathrm{mrem}$. Cleanup is anticipated to be completed in 2010 . 
- Acceleration of verification activities and the subsequent shipment of legacy transuranic waste to WIPP for a schedule acceleration of two years with closure of the project anticipated to be in 2007.

- NDEP will continue its long-standing constructive, cooperative partnership with the NNSANV EM program to ensure state regulator goals and objectives are met through expedited cleanup of activities under the purview of the FFACO. The regulator will provide proactive, appropriately focused, and timely review and comments on all applicable regulatory documents. In turn, NNSA/NV EM will ensure that all state oversight programs (cleanup and AIP) are properly funded to meet its obligations in support of the NNSANNV EM program. The long-standing constructive cooperative working relationship between NDEP and NNSA/NV EM has positively effected changes in NNSA/NV EM priorities, strategies, work practices, and commitments; and created an environment for dealing with other issues, including ones having impact to the DOE complex.

- $\quad$ NNSA/NV EM will continue their stakeholder involvement program to ensure the public is appropriately involved in providing advice and recommendations regarding activities under the purview of NNSA/NV EM.

- The NNSANV EM program will, to the extent authorized by Federal and/or State law(s), operate its low-level and mixed-low-level waste disposal facilities. The NDEP will continue to process NNSA/NV's RCRA Part B Application for a disposal facility for mixed wastes from the complex, and it is anticipated that all requirements and programmatic issues related to the Application will be acceptably addressed and resolved by September 2003. The NDEP will continue to carry out its low-level waste oversight responsibilities in accordance with the Joint DOE/State Low-Level Waste Oversight Agreement, effective July 1, 1999, (Attachment X to the Agreement in Principle Between the Department of Energy and the State of Nevada).

- $\quad$ NNSANV EM and the state regulator will continue to evaluate opportunities under terms of the FFACO to improve cost and schedule performance of agreement activities.

- NNSANV and its contractors will complete an internal commitment document that focuses on accelerated cleanup and maintenance of waste disposal capability.

- $\quad$ NNSANNV EM considers this Letter of Intent, together with achievement of the items delineated above, to meet the objectives called for in the President's fiscal year 2003 budget request for sites to reach new agreements with state and federal regulators to help accelerate and improve cleanup performance.

- DOE and its contractors will develop a Performance Plan by August 2002. The plan will include actions, milestones, responsibilities, business processes, and acquisition strategies necessary to achieve the agreements made in this letter. The Department recognizes that funding commensurate with the approved performance plan is necessary to achieve the abovestated goals of acceleration and closure. NDEP will review the performance plan to assure that the previously agreed to funding for the baseline scope of work as well as funding for the incremental accelerated cleanup activities are sufficient to implement this Letter of Intent. 
- $\quad$ NNSANV is actively engaged in implementing strong, aggressive project management and business/contract management within its activities, processes, and contracts to ensure costeffective, efficient management and acceleration of activities under its purview. Using these systems, NNSANV EM will demonstrate its ability to achieve the actions described in this Letter of Intent.

We, the undersigned, are committed to work together to implement these work plan agreements, the actions in this Letter of Intent, and to seek additional opportunities to accelerate and improve cleanup.

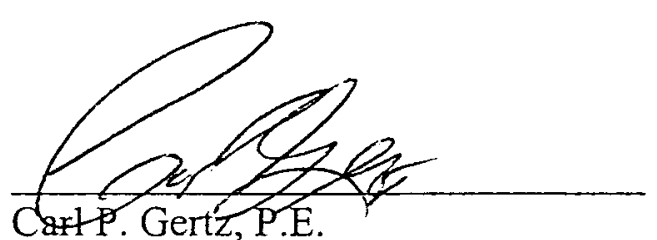

Assistant Manager for Environmental Management

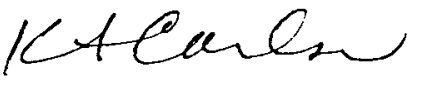

Kathleen A. Carlson

Manager

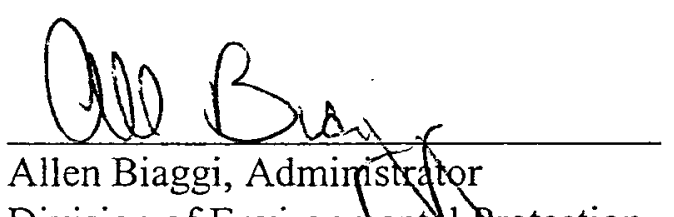

Division of Environment a Protection Department of Conservation d Natural Resources

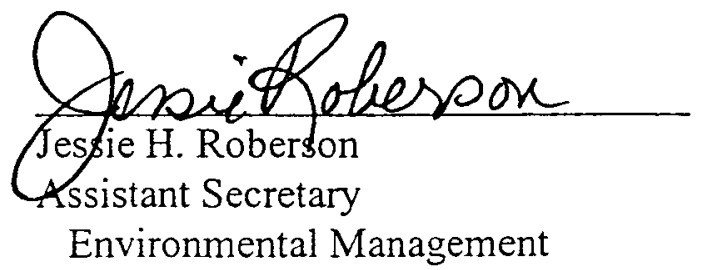

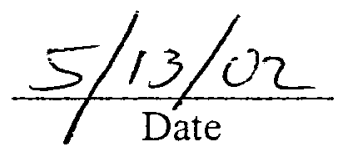
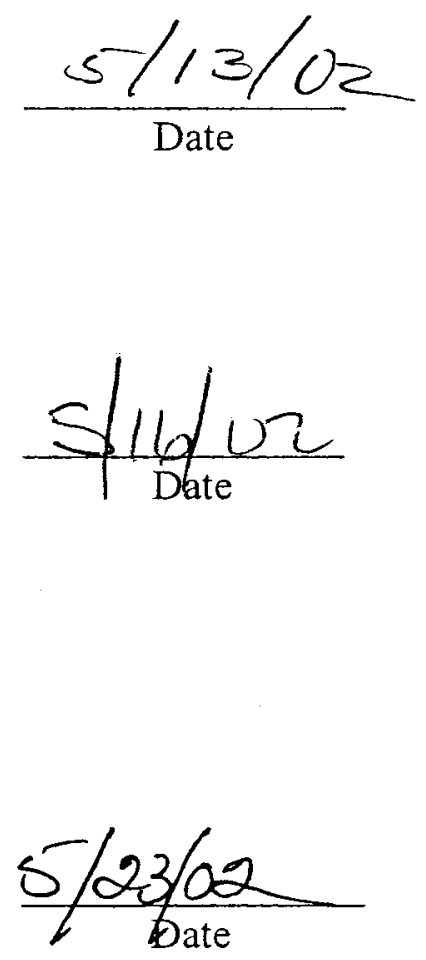
Appendix E

Commitment Letters 


\section{Commitment Letters}

Following this page are the federal and contractor commitment letters to accelerate closure of the environmental management activities under the U.S. Department of Energy, National Nuclear Security Administration Nevada Operations Office (NNSA/NV). The first letter identifies the commitments between the NNSA/NV and DOE Headquarters. The second letter identifies commitments between NNSA/NV and its environmental management contractors. 


\section{DOE COMMITMENT TO ACCELERATED RISK CLOSURE AT THE NEVADA OPERATIONS OFFICE}

The Department of Energy and the Nevada Operations Office agree to achieve the safe, accelerated risk reduction and early completion of three projects: Industrial Sites (2008), Soils (2010), and Transuranic Waste (2007). To achieve this goal:

\section{Nevada Operations Office will:}

$\checkmark \quad$ Develop a critical path schedule that articulates key decisions, major milestones, significant known barriers, and funding requirements.

Develop a government-furnished services and items (GFS\&I) lists required to complete accelerated risk reduction and cleanup.

$\checkmark \quad$ Report progress of accelerated risk reduction and cleanup project against the revised baseline.

$\checkmark \quad$ Continue to work proactively with the regulators and stakeholders in resolving site issues, while aggressively pursuing further opportunities for acceleration.

Rapidly work issues with Headquarters that require DOE support or action to resolve.

Maintain waste disposal capability at the Nevada Test Site for low-level and mixed-low-level waste.

\section{DOE Headquarters will:}

$\checkmark \quad$ Actively assist Nevada in overcoming barriers and obstacles to expedite accelerated risk reduction and cleanup. This includes proactive work in areas such as safeguards and security, contracts, oversight, authorization basis, etc.

$\checkmark \quad$ Avoid or prevent any expansion in EM scope, mission, or requirements that is not consistent with achieving safe, accelerated risk reduction and cleanup.

$\checkmark$ Reform EM internal business processes to ensure the DOE supports and drives accelerated risk reduction and cleanup.

$\checkmark \quad$ Work with Nevada to develop and execute acquisition and contract strategies that improve contracting practices.

Actively work to ensure that waste management policies are consistent with risk posed to human health and environment.

$\checkmark \quad$ Ensure National Environmental Policy Act (NEPA) reviews are completed in cost-effective, technically based manner that support timely decision making by DOE senior management and support the accelerated risk reduction and cleanup actions at the Nevada Test Site. 
$\checkmark \quad$ Ensure that the refocused Science and Technology Program actively works to provide costeffective, real time solutions to challenges in accelerating risk reduction and cleanup at the Nevada Test Site.

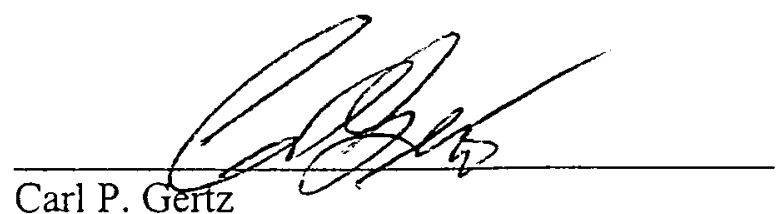

Assistant Manager

for Environmental Management

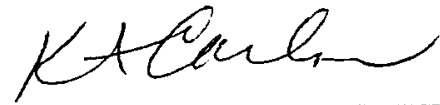

Kathleen A. Carlson

Manager

Jessie H. Roberson

Assistant Secretary

Environmental Management
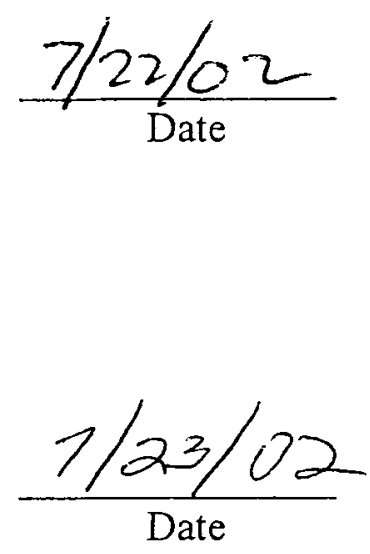

Date 
The Department of Energy, National Nuclear Security Administration Nevada Operations Office (NNSA/NV) Environmental Management (EM) program; Bechtel Nevada; and IT Corporation agree to work to complete baselined activities on an expedited schedule for the Industrial Sites, Soils, and Transuranic Waste Projects. To achieve this goal:

\section{NNSA/NV EM Contractors will:}

$\checkmark \quad$ Pro-actively seek additional ways to improve performance.

Use best-in-class management practices, lessons learned, and project managers in the NNSA/NV EM program.

Update the life-cycle baseline to support accelerated risk reduction and cleanup of the Industrial Sites, Soils, and Transuranic Waste Projects.

$\checkmark \quad$ Develop a critical path to support accelerated cleanup that articulates key decisions, major milestones, significant known barriers, and funding requirements.

$\checkmark \quad$ Restructure labor agreements to optimally support accelerated risk reduction and cleanup.

$\checkmark \quad$ Restructure workforce, as required, to deliver the expedited schedules for the Industrial Sites, Soils, and Transuranic Waste Projects.

$\checkmark \quad$ Commit to improved implementation of Integrated Safety Management and continuing improvement of safety performance.

$\checkmark \quad$ Report progress of EM cleanup against the revised baselines for the Industrial Sites, Soils, and Transuranic Waste Projects.

$\checkmark \quad$ Continue to work proactively with the regulators and stakeholders in resolving site issues.

$\checkmark \quad$ Rapidly work issues with the Nevada Operations Office that require DOE support or action to resolve.

\section{Nevada Operations Office will:}

$\checkmark$ Restructure, realign, and focus contract incentives that drives performance and will deliver the revised project baselines.

$\checkmark \quad$ Become a better contract manager, ensuring all interactions with the contractor add value in achieving safe accelerated risk reduction mission.

$\checkmark \quad$ Restructure and realign Federal workforce, as necessary, to support the revised EM baselines.

$\checkmark \quad$ Develop and implement a predictable, reliable, and standards-based oversight and assessment process. 
$\checkmark \quad$ Avoid or prevent any expansion in EM scope, mission, or requirements that is inconsistent with achieving safe, accelerated cleanup.

$\checkmark \quad$ Reform internal business processes to ensure support of accelerated risk reduction and cleanup.

$\checkmark \quad$ Ensure National Environmental Policy Act (NEPA) reviews are completed in cost-effective, technically based manner that support timely decision making by DOE senior management and support the accelerated cleanup actions.

$\checkmark \quad$ Ensure that the site's Science and Technology Program actively works to provide cost-effective, real time solutions to challenges in accelerating risk reduction and cleanup.
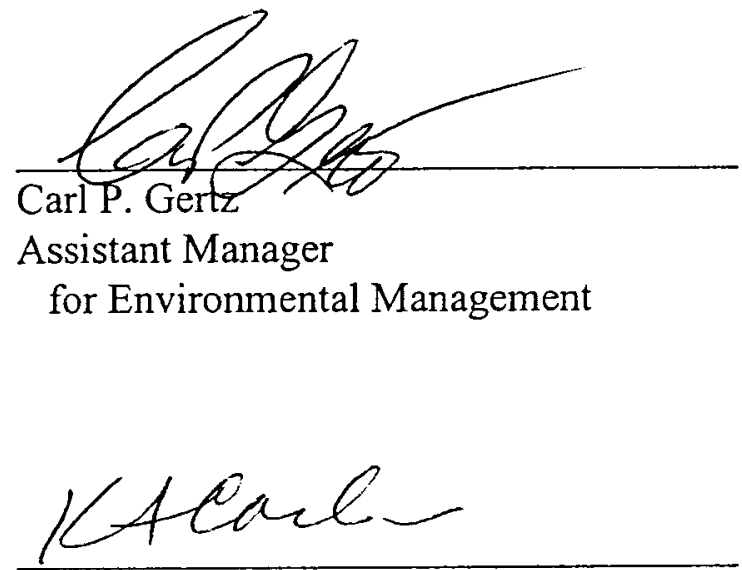

Kathleen A. Carlson

Manager

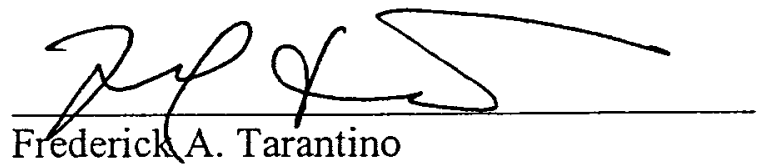

President \& General Manager

Bechtel Nevada

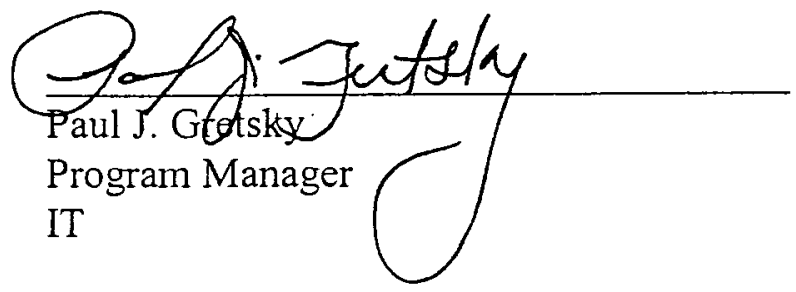

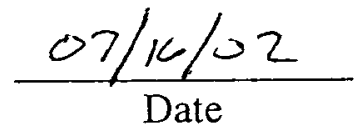

$\frac{7 / 23 / 02}{\text { Date }}$
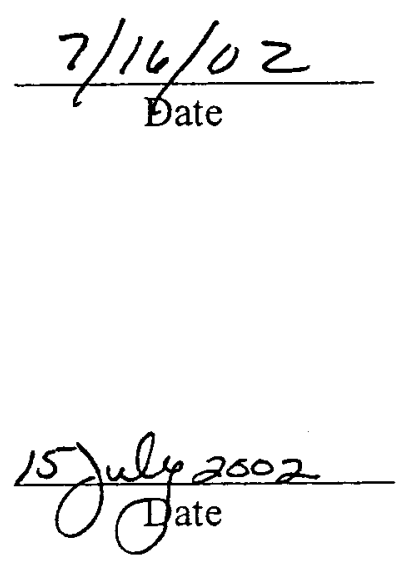
Appendix F

Endorsement Letters 


\section{Endorsement Letters}

Following this page are endorsement letters from the State of Nevada and the Nevada Test Site Programs Community Advisory Board (NTS CAB). The letters document support for acceleration of the U.S. Department of Energy, National Nuclear Security Administration Nevada Operations Office, Environmental Management Program activities. 


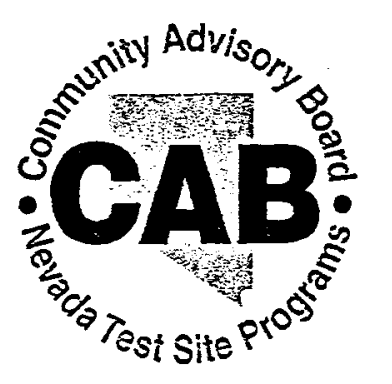

Philip Claire, CAB Chair Cynthia Ortiz, CAB Vice-Chair

Kaye Allisen-Medlin

Dennis Bechtel

Pauline Esteves

Michael Genge, Chair

Transportation Waste

Committee

Herbert Inhaber

Bill King

Peter Krenkel, Co-Chair

Program/Public Outreach

Committee

Audna Lang

Marian Lawrence

Genne Nelson

Richard Nocilla, Co-Chair

Program/Public Outreach

Committee

Frank Overbey, Jr.

Herbert Paperno

John Pawlak, Chair

Diversification Committee

Kathleen Peterson, Chair

UGTA Committee

Charles Phillips

Richard Pocker

Ken Reim, Chair

Budget Committee

Marsha Smith

Engelbrecht von Tiesenhausen

\section{Ex-Officio Members}

Carl Gertz

U.S. Department of Energy,

Nevada Operations

Tiffany Lantow

Defense Threat Reduction Agency

Paul Liebendorfer

State of Nevada Division of

Environmental Protection

Frank Tussing

Nevada Alliance for Defense,

Energy, and Business

Brent Babcock

Nye County

Technical Advisor

Earle Dixon

Support Staff

Kay Planamento

\section{Community Advisory Board for Nevada Test Site Programs}

July 12,2002

Mr. Carl P. Gertz, P.E.

Assistant Manager for Environmental

Management

Nevada Operations Office

U.S. Department of Energy, National Nuclear Security Administration

PO Box 98518

Las Vegas, NV 89193-98518

Re: Review of NNSA/NV EM's Performance Management Plan

Dear Mr. Gertz:

Thank you for the opportunity to review and comment on NNSANV EM's Performance Management Plan (PMP) that is being developed for the expedited cleanup and risk reduction activities at the Nevada Test Site (NTS). The Community Advisory Board (CAB) supports a cost effective approach to cleanup and risk reduction activities at the NTS. The CAB also strongly urges site officials and regulators to continue to work together to identify and promptly implement opportunities to accelerate cleanup and risk reduction activities.

Although the $C A B$ just received the draft PMP July 10th, within the next several weeks, the $\mathrm{CAB}$ Budget Committee will take a close look at the PMP to develop recommendations for the entire $C A B$ 's consideration.

In our letter dated July 12,2002 , the CAB provided feedback on both the May 13, 2002, signed "Letter of Intent" as well as the Top-to-Bottom Review. We look forward to a response from you to that letter, and will forward recommendations to you related to the PMP as soon as the $\mathrm{CAB}$ reaches consensus on the issues.

Sincerely,

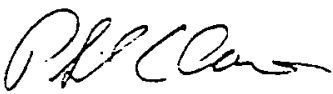

Philip Claire, Chair

Community Advisory Board

for Nevada Test Site Programs

cc: Paul Liebendorfer, NDEP

CAB Members 


\section{Community Advisory Board for Nevada Test Site Programs}

Philip Claire, $C A B$ Chair Cynthia Ortiz, CAB Vice-Chair

Kaye Allisen-Medlin

Dennis Bechtel

Pauline Esteves

Michael Genge, Chair

Transportation Waste

Committee

Herbert Inhaber

Bill King

Peter Krenkel, Co-Chair

Program/Public Outreach

Committee

Audna Lang

Marian Lawrence

Genne Nelson

Richard Nocilla, Co-Chair

Program/Public Outreach

Committee

Frank Overbey, Jr.

Herbert Paperno

John Pawlak, Chair

Diversification Committee

Kathleen Peterson, Chair

UCTA Committee

Charles Phillips

Richard Pocker

Ken Reim, Chair

Budget Committee

Marsha Smith

Engelbrecht von Tiesenhausen

Ex-Officio Members

Carl Gertz

U.S. Department of Energy,

Nevada Operations

Tiffany Lantow

Defense Threat Reduction Agency

Paul Liebendorfer

State of Nevada Division of

Environmental Protection

Frank Tussing

Nevada Alliance for Defense,

Energy, and Business

Brent Babcock

Nye County

Technical Advisor

Earle Dixon

Support Staff

Kay Planamento
July 12,2002

Ms. Jessie H. Roberson,

Assistant Secretary for Environmental Management

U.S. Department of Energy

1000 Independence Ave., SW

Washington, DC 20585

Ms. Kathleen A. Carlson, Manager

Nevada Operations Office

U.S. Department of Energy, National Nuclear Security Administration

PO Box 98518

Las Vegas, NV 89193-98518

Mr. Carl P. Gertz, P.E.

Assistant Manager for Environmental

Management

Nevada Operations Office

U.S. Department of Energy, National Nuclear Security Administration

PO Box 98518

Las Vegas, NV 89193-98518

Mr. Allen Biaggi, Administrator

Nevada Division of Environmental Protection

Department of Conservation and Natural Resources

333 W. Nye Lane, Room 138

Carson City, Nevada 89706-0851

RE: Accelerated Cleanup Reform for NNSA/NV's Nevada Test Site

Dear Ms. Roberson, Ms. Carlson, Mr. Gertz, and Mr. Biaggi:

The May 13,2002, Letter of Intent documents the commitment by the State of Nevada, Division of Environmental Protection (NDEP); National Nuclear Security Administration (NNSA) Nevada Operations Office (NV), Environmental Management (EM); and U.S. Department of Energy (DOE) to accelerate cleanup and reduce risks for major projects at the Nevada Test Site (NTS) by 2010, 
Page 2

July 12, 2002

rather than 2020. DOE-HQ reduced the NNSANTS EM-planned FY 2003 budget of $\$ 90.5 \mathrm{M}$ to $\$ 61$ $\mathrm{M}$, compared to the FY 2002 budget of $\$ 85 \mathrm{M}$. Based on this Letter of Intent and the Accelerated Cleanup Reform Account (ACRA), the DOE-HQ has since provided an additional $\$ 33 \mathrm{M}$ for FY2003, which includes $\$ 5 \mathrm{M}$ for NNSA/NTS EM salaries and related expenses. The CAB understands the additional $\$ 33 \mathrm{M}$ is intended for the sole purpose of accelerating cleanup and reducing risks, thus increasing FY 2003 monies to $\$ 94 \mathrm{M}$. The Community Advisory Board (CAB) for Nevada Test Site Programs hereby presents the following comments and recommendations.

1. The CAB supports acceleration of the Industrial Sites Project corrective actions and the anticipated completion date of 2008, or earlier. The NNSANV has stated that the recent consolidation of Corrective Action Units (CAUs) into larger groups is projecting a forward cost reduction of $\$ 70 \mathrm{M}$. The CAB requests that the interaction and cooperation between NNSA/NV and the NDEP which brought about this cost-reduction strategy continues and is applied to other projects.

2. The $C A B$ will support the Letter of Intent principle that the Underground Test Area (UGTA) Project implement the recently renegotiated corrective action strategy and the following. The Peer Review in 2001 found a number of major deficiencies in the UGTA strategy, and recommended key improvements be implemented. The $C A B$ will support the UGTA strategy when the recommendations of the Peer Review and $\mathrm{CAB}$ have been implemented in the FY 2003 scope of work. The $\mathrm{CAB}$ will provide more detailed recommendations on the UGTA Project in the near future.

3. The CAB supports the Letter of Intent principle for acceleration of corrective actions for the Plutonium Soils Project and the anticipated completion date of 2010. The $C A B$ is pleased to see that the U.S. Air Force, the NDEP, and the NNSA/NV are working on an agreed clean-up level. The $\mathrm{CAB}$ requests the opportunity to comment on the draft agreements and all associated costs for cleanup.

4. The CAB supports the Letter of Intent principle for the acceleration of verification activities and the subsequent shipment of legacy transuranic (TRU) waste to the Waste Isolation Pilot Plant (WIPP) by two years, and the anticipated closure of the project in 2007. The NTS has a limited amount of TRU waste, and the CAB strongly suggests this project reach closure before 2007 . This would make available more funding for the accelerated cleanup and risk reduction of other EM projects in Nevada.

5. The CAB supports the Letter of Intent principle that NNSA/NV continue their stakeholder involvement program. The $\mathrm{CAB}$ has a responsibility to inform stakeholders, especially stakeholders from the situs county, Nye, which bears all the immediate and future impacts of the NTS mission.

6. The CAB supports the Letter of Intent principle that the NNSA/NV program continue to operate its low-level waste (LLW) facility. Even though the disposal of offsite radioactive waste 
results in a risk increase for the NTS, the $C A B$ strongly supports cleanup and risk reduction at other sites in the DOE complex. The CAB contends that since offsite waste disposal operations at the NTS will continue and expand, the NNSANN EM annual budget should remain stable for at least the next decade as an equitable compensation for the risk increase in Nevada for this activity. DOE-HQ needs to coordinate the steady movement of low-level waste from around the DOE complex to the NTS, in order to maximize the use of personnel and equipment, thus significantly reducing NNSA/NV and DOE complex costs.

7. The CAB has just received the NTS Performance Management Plan and looks forward to the opportunity to review and comment on how NNSA/NV intends to measure, accomplish, and improve its management of EM activities in Nevada. The CAB is supportive of NNSA/NV plans to accelerate cleanup and risk reduction activities at the NTS in a manner that is open, cost effective, and efficient, as well as acceptable to informed Nevada stakeholders. The CAB also strongly supports the implementation of the February 4, 2002, Top-to-Bottom report showing an urgency to clean up and reduce risks at all DOE complex sites, and every effort should be made to accelerate closure by 2 years.

This May 13, 2002, Letter of Intent is comparable to many similar documents that promised improvements, cost reductions and accelerated cleanup. However, we are not aware of management systems, past or present, that assured promised improvements will be made.

We thank you for the opportunity to provide comments and look forward to your response to the above CAB recommendations.

Sincerely,

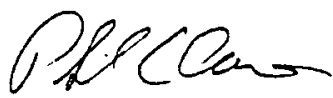

Philip Claire, Chair

Community Advisory Board

for Nevada Test Site Programs 
TIग)

Milinirasistatisת

Fursimill 6xis

Wiater Pollution Cintrot

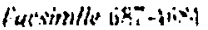

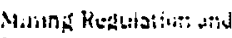

Rosizmatior:

fucsinite ist 0.505

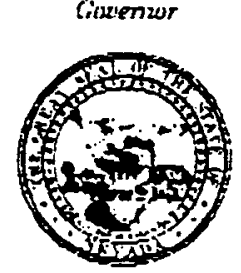

DLFARTMEAT OF CONSBRVATION ANI NATLRAL RFSOMIRCES

\section{DIVISION OF ENVIRONMENTAL PROTECTION}

3.33 W. Nye Lunc, Ronm 138

Carson City, Nevada 89706

July 31,2002
Wasic Moraglenkint Correstive Astions federal tionditirs

Air Quality:

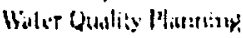
Fatsimile isto-ti3tis

Ms. Jessie Hill Roberson

Assistant Secretary for

Environmental Management

U.S. Department of Energy

1000 independence Avenuc S.W.

Washington D.C. 20585

Dear Ms. Roberson:

\section{SUPPORT FOR THE PERFORMANCE MANAGEMENT PLAN FOR THE NATIONAL NUCLEAR SECURITY ADMINISTRATION, NEVADA OPERATIONS OFFICE}

The Nevada Division of Environmental Protection (NDEP) and National Nuclear Security Administration Nevada Operations office (NNSANV) Environmental Management Program have been working cooperatively over many years to define new cost cffective ways of conducting remediation and waste management activities on the sites in Nevada. The most current effort in that regard is contained in the Letter of Intent (LOD), jointly signed in May 2002, identifying four areas for accelerating these activities. Il was recognized in the LOI that a commitment to secure the funding required is necessary if these actions are to be accomplished. It must be emphasized that only with a sustained level of funding will NNSANV be able to keep these commitments.

In the LOI, NNSA/NV committed to develop a Performance Management Plan (PMP) that would detail how the identificd actions would be accomplished. The current draft PMP identifies achievements to date and those actions that need to be undertaken to accomplish our mutual long term objectives, completing site remediation and appropriatc waste management. The Draft PMP identifies actions and schedules 10 accomplish the following: 
Completion of all industrial Sites remedial actions in FY'03 and FY'04 for which Deadlines have been established and proposes an aggressive schedule for completing the remaining sites by 2008 ;

A commitment to work with all parties to effectively implement the recently renegotiated strategy in the UGTA project;

Remediation of the Soil sites Clean Slates and Double Tracks plutonium (PU) impacted arcas on the Air Force Range lands at an action level agreed to by the lacal Air Force command. Verification that the agreed to remediation level of $1000 \mathrm{pCi} / \mathrm{y}$ of $\mathrm{PU}$ is an acceptable level for the current and future range operating conditions is presently pending at the Office of the Secretary of the Air Force;

Characterization and shipment to WIPP of drums of legacy TRU/Mixed TRU waste ahead of existing Site Treatment Plan Deadlines.

The draft PMP also proposes a number of new initiatives and out year activities where proposed actions have not been fully discussed and agreements reached. The establishment of remediation levels for radiologically contaminated soils for nuclides other than plutonium for locations both on and off the NTS, treatment and disposal options for classified and nonstandard containers of TRU wastes, full operation of mixed and low level waste disposal facilities and a commitment to long term stewardship are just a few of the challenges in our future.

There are numerous policy and regulatory issues that remain to be resolved, but we are committed to collaboratively working with NNSANV to address all of these concerns and achieve our mutual goals. However, site remediation and acceptable waste management and disposal activities can only be achiovod when the necessary funding continues to be made available.

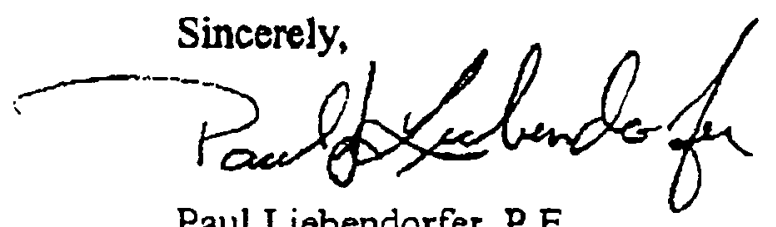

Paul Liebendorfer, P.E.

Chief 